\title{
Advances in the understanding and management of T-cell prolymphocytic leukemia
}

\author{
Kamel Laribi ${ }^{1}$, Pierre Lemaire ${ }^{2}$, Jeremy Sandrini ${ }^{3}$ and Alix Baugier de Materre ${ }^{4}$ \\ ${ }^{1}$ Department of Hematology, Centre Hospitalier du Mans, Le Mans, France \\ ${ }^{2}$ Laboratory of Biology and Hematology, Centre Hospitalier du Mans, Le Mans, France \\ ${ }^{3}$ Laboratory of Anatomopathology, Centre Hospitalier du Mans, Le Mans, France \\ ${ }^{4}$ Department of Medicine, Clinique du Pré, Le Mans, France
}

Correspondence to: Kamel Laribi, email: klaribi@ch-lemans.fr

Keywords: T-cell prolymphocytic leukemia, morphology, cytogenetic, molecular biology, treatment

Received: February 13, 2017

Accepted: August 27, 2017

Published: November 01, 2017

Copyright: Laribi et al. This is an open-access article distributed under the terms of the Creative Commons Attribution License 3.0 (CC BY $3.0)$, which permits unrestricted use, distribution, and reproduction in any medium, provided the original author and source are credited.

\section{ABSTRACT}

T-prolymphocytic leukemia (T-PLL) is a rare T-cell neoplasm with an aggressive clinical course. Leukemic T-cells exhibit a post-thymic T-cell phenotype ( $\mathrm{Tdt}^{-}, \mathrm{CD}^{-} \mathrm{a}^{-}$, $\mathrm{CD5}^{+}, \mathrm{CD2}^{+}$and $\mathrm{CD7}^{+}$) and are generally $\mathrm{CD4}^{+} / \mathrm{CD8}^{-}$, but $\mathrm{CD4}^{+} / \mathrm{CD8}^{+}$or $\mathrm{CD8}^{+} /$ CD4- T-PLL have also been reported. The hallmark of T-PLL is the rearrangement of chromosome 14 involving genes for the subunits of the T-cell receptor (TCR) complex, leading to overexpression of the proto-oncogene TCL1. In addition, molecular analysis shows that T-PLL exhibits substantial mutational activation of the IL2RG-JAK1-JAK3-, STAT5B axis. T-PLL patients have a poor prognosis, due to a poor response to conventional chemotherapy. Monoclonal antibody therapy with antiCD52alemtuzumab has considerably improved outcomes, but the responses to treatment are transient; hence, patients who achieve a response to therapy are considered for stem cell transplantation (SCT). This combined approach has extended the median survival to four years or more. Nevertheless, new approaches using well-tolerated therapies that target growth and survival signals are needed for most patients unable to receive intensive chemotherapy.

\section{INTRODUCTION}

Significant progress has been made in the understanding of T-PLL through better characterization by flow cytometry and identification of genomic and molecular abnormalities involved in its pathophysiology [1-4]. The prognosis remains poor with current treatment. Targeted therapies involving growth and survival signals, such as the JAK-STAT pathway, could be effective therapeutic options

Diagnosis by morphology and flow cytometry

T-PLLs generally have a classic prolymphocytic morphology consisting of medium-sized cells and a high nuclear/cytoplasmic ratio, condensed chromatin, basophilic cytoplasm with cytoplasmic blebs, and a single prominent nucleolus (Figures 1, 2). In half of cases, the cells contain regular, round or oval, nuclei, whereas in the rest, the nuclei are irregular and often convoluted, resembling those seen in Sezary syndrome (Figures 3A, 3B) or ATLL cells (Figure 4). In 25\% of cases, the cells are small, indistinguishable from CLL cells, or cerebriform (Figures 2,5) and the nucleolus is not easily visible by light microscopy, as it is masked by the highly-condensed chromatin [1, 5-7]. Skin lesions are characterized by leukemia cutis with perivascular and periadnexal infiltrates containing irregular, small to medium-sized lymphocytes, without epidermotropism (Figures 6-7). Infiltration of lymph nodes is often diffuse, with paracortical expansion in some cases (Figures 8-9).

By flow cytometry, T-PLL exhibits a post thymic (TdT-, CD1a-), mature T-cell immunophenotype (CD2+, CD5+, CD7+, CD16-, and CD56-) and variable CD4 and 
CD8 expression (Table 1). The leukemic lymphocytes are generally CD4+/CD8-, but significant subsets coexpress CD4 and CD8, or are CD8+/CD4-. A CD4-/CD8phenotype has also been reported in very rare cases. $\mathrm{CD} 7$ is also generally highly expressed [1, 2, 8, 9] T-PLL patients are also negative for human T-cell leukemia virus type 1 .
The cells of T-PLL patients are of mostly the TCR $\alpha \beta$ phenotype, whereas only rare cases of TCR $\gamma \delta$ expression have been reported. CD3 and TCR $\beta$ may be lacking at the surface of T-PLL cells, but they are always found in the cytoplasm, and the TCR $\beta$ and/or $\gamma$ chain genes are rearranged in all cases $[1,8,10]$.

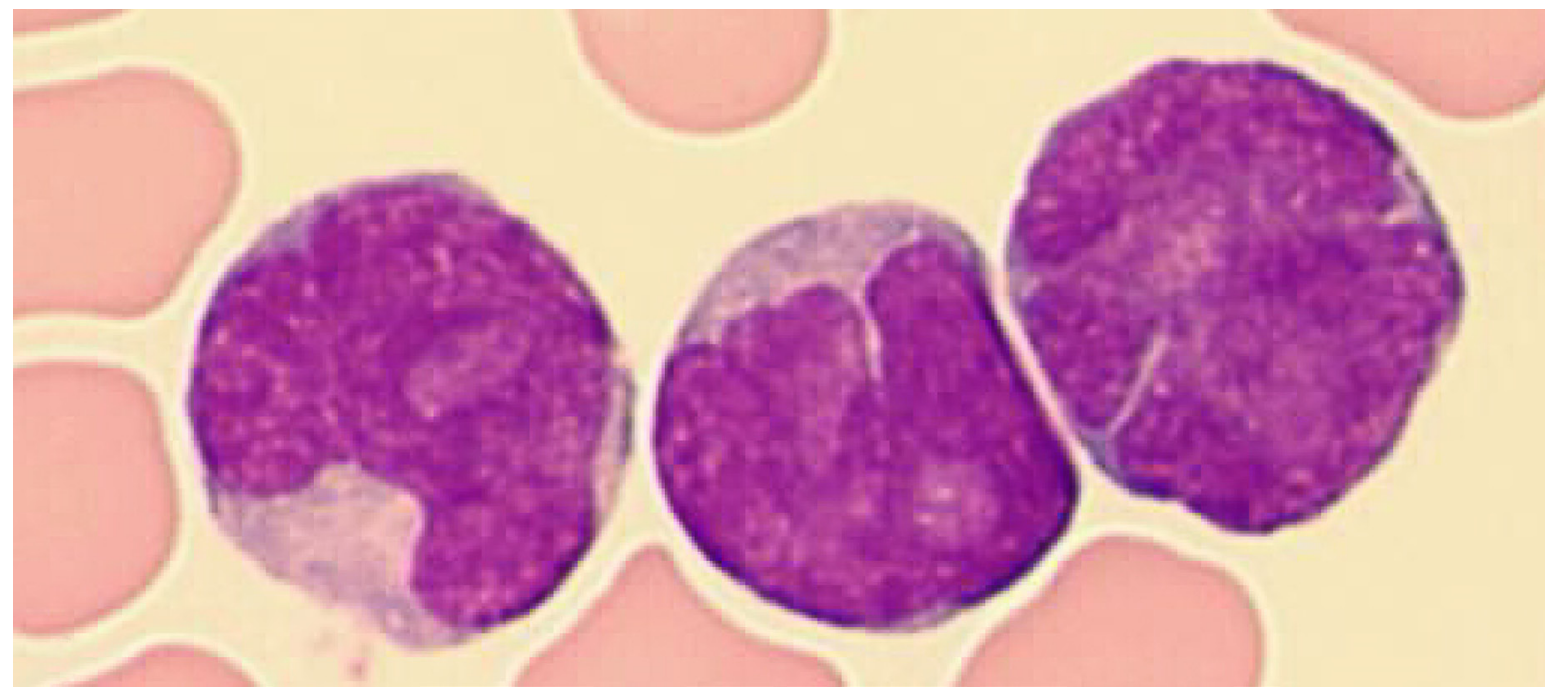

Figure 1: Small cells containing distinct nucleoli, irregular nuclei, and slightly basophilic cytoplasm (classical form) (MGG, X 100).

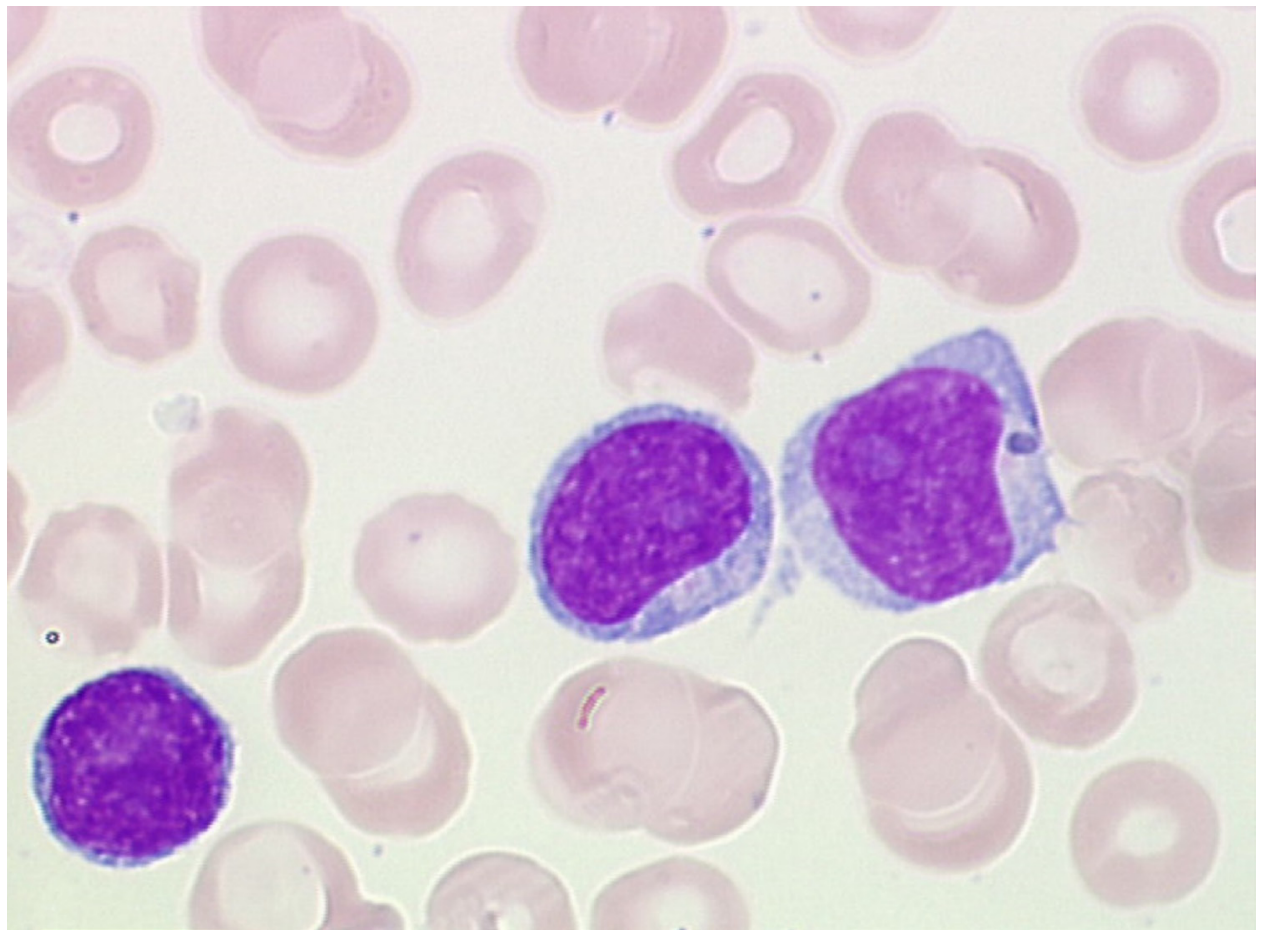

Figure 2: Small cell with inconspicuous nucleoli and a regular nucleus indistinguishable from CLL cells. Two larger cells with distinct nucleoli, round-oval nuclei, and basophilic cytoplasm (MGG, X 100). 
Table 1: Immunophenotypic markers in T-PLL

\begin{tabular}{|c|c|c|c|c|c|c|c|c|}
\hline \multirow[b]{2}{*}{ Immunophenotype } & \multicolumn{2}{|c|}{ Matutes (1) } & \multicolumn{2}{|c|}{ Chen (2) ${ }^{\mathrm{a}}$} & \multicolumn{2}{|c|}{ Garant (9) $^{\mathrm{b}}$} & \multicolumn{2}{|c|}{ Garant (9) } \\
\hline & $\begin{array}{l}\text { Number of } \\
\text { cases tested }\end{array}$ & $\%$ positive & $\begin{array}{c}\text { Number } \\
\text { of cases } \\
\text { tested }\end{array}$ & $\%$ positive & $\begin{array}{c}\text { Number } \\
\text { of cases } \\
\text { tested }\end{array}$ & $\%$ positive & $\begin{array}{c}\text { Number } \\
\text { of cases } \\
\text { tested }\end{array}$ & $\%$ positive \\
\hline CD1a & 55 & 0 & 11 & 0 & 38 & 3 & 13 & 0 \\
\hline $\mathrm{CD} 2$ & 77 & 99 & 29 & 100 & 53 & 100 & 18 & 94 \\
\hline CD3 & 68 & 81 & 29 & 89.7 & 53 & 94 & 19 & 89 \\
\hline CD5 & 27 & 100 & 29 & 100 & 51 & 100 & 18 & 100 \\
\hline CD7 & 56 & 93 & 29 & 100 & 46 & 93 & 14 & 93 \\
\hline CD4+CD8- & 72 & 65 & 29 & 37.9 & 53 & 60 & 19 & 74 \\
\hline CD4+CD8+ & 72 & 21 & 29 & 41.4 & 53 & 17 & 19 & 24 \\
\hline CD4-CD8+ & 72 & 13 & 29 & 17.2 & 53 & 15 & 19 & 0 \\
\hline CD4-CD8- & 72 & 1 & 29 & 3.4 & 53 & 8 & 19 & 6 \\
\hline $\mathrm{CD} 25$ & 44 & 18 & 17 & 35.3 & 33 & 15 & 10 & 20 \\
\hline CD38 & 33 & 52 & & & 17 & 53 & 10 & 20 \\
\hline HLA-DR & 52 & 8 & & & 41 & 0 & 11 & 9 \\
\hline CD10 & & & 23 & 0 & 34 & 3 & 15 & 0 \\
\hline CD16 & & & 10 & 0 & & & & \\
\hline CD34 & & & 27 & 0 & & & & \\
\hline CD45 & & & 29 & 93.1 & & & & \\
\hline CD52 & & & 19 & 100 & & & & \\
\hline CD56 & & & 29 & 0 & 30 & 3 & 11 & 0 \\
\hline TdT & & & 22 & 0 & & & & \\
\hline $\mathrm{T} \alpha \beta^{+}$ & 25 & 60 & & & 23 & 96 & 11 & 82 \\
\hline $\mathrm{T} \gamma \delta^{+}$ & & & & & 23 & 0 & 11 & 0 \\
\hline $\mathrm{CD}^{2} 5 \mathrm{RO}^{+} \mathrm{CD}^{2} 5 \mathrm{RA}^{-}$ & & & & & 18 & 83 & 10 & 10 \\
\hline $\mathrm{CD}^{2} 5 \mathrm{RO}^{-} \mathrm{CD}^{2} 5 \mathrm{RA}^{+}$ & & & & & 18 & 11 & 10 & 40 \\
\hline $\mathrm{CD}^{2} 5 \mathrm{RO}^{+} \mathrm{CD}^{2} 5 \mathrm{RA}^{+}$ & & & & & 18 & 6 & 10 & 10 \\
\hline $\mathrm{CD}^{2} 5 \mathrm{RO}^{-} \mathrm{CD}^{-} 4 \mathrm{RA}^{-}$ & & & & & 18 & 10 & 10 & 40 \\
\hline
\end{tabular}

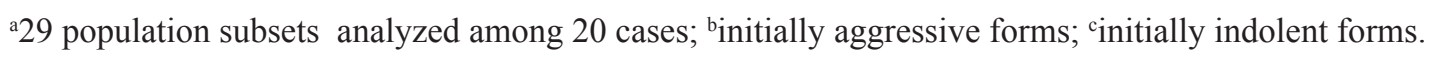

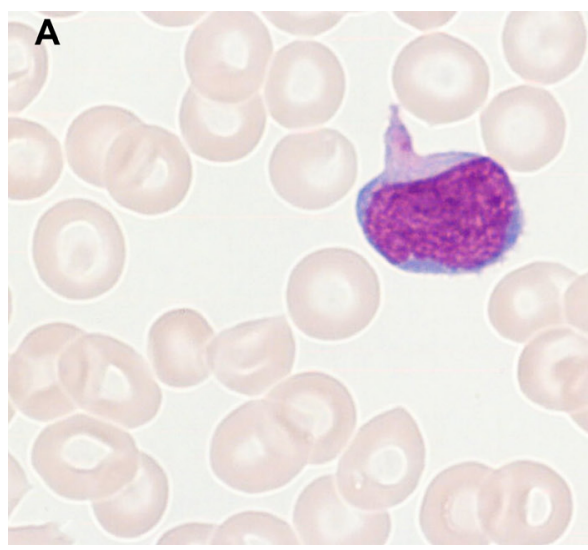

Figure 3: Small cell with fine chromatin, cytoplasmic extensions, inconspicuous nucleoli, and basophilic cytoplasm (A). Small cell with distinct nucleoli and folded (wrinkled) nucleus (B): Sezary aspect (MGG, X 100). 
There is generally high CD45 expression except for rare cases [2]. CD52, a glycosylphosphatidylinositol-linked protein present on normal and malignant lymphocytes and frequently targeted therapeutically in T-PLL, is expressed at high density in most T-PLL cases [11].

Markers related to T-cell activation, such as CD25, class II HLA-DR, and CD38 may or may not be expressed
$[1,2,9]$, whereas all T-PLL cases are negative for the T-cell Intracellular Antigen 1(TIA-1), a cytotoxic granule -associated protein expressed by cytotoxic T-cells, even in cases with a CD8+ phenotype [12].

CD117 (KIT), a type III receptor tyrosine kinase that participates in intracellular signal transduction in several cell types, is associated with the myeloid lineage, usually

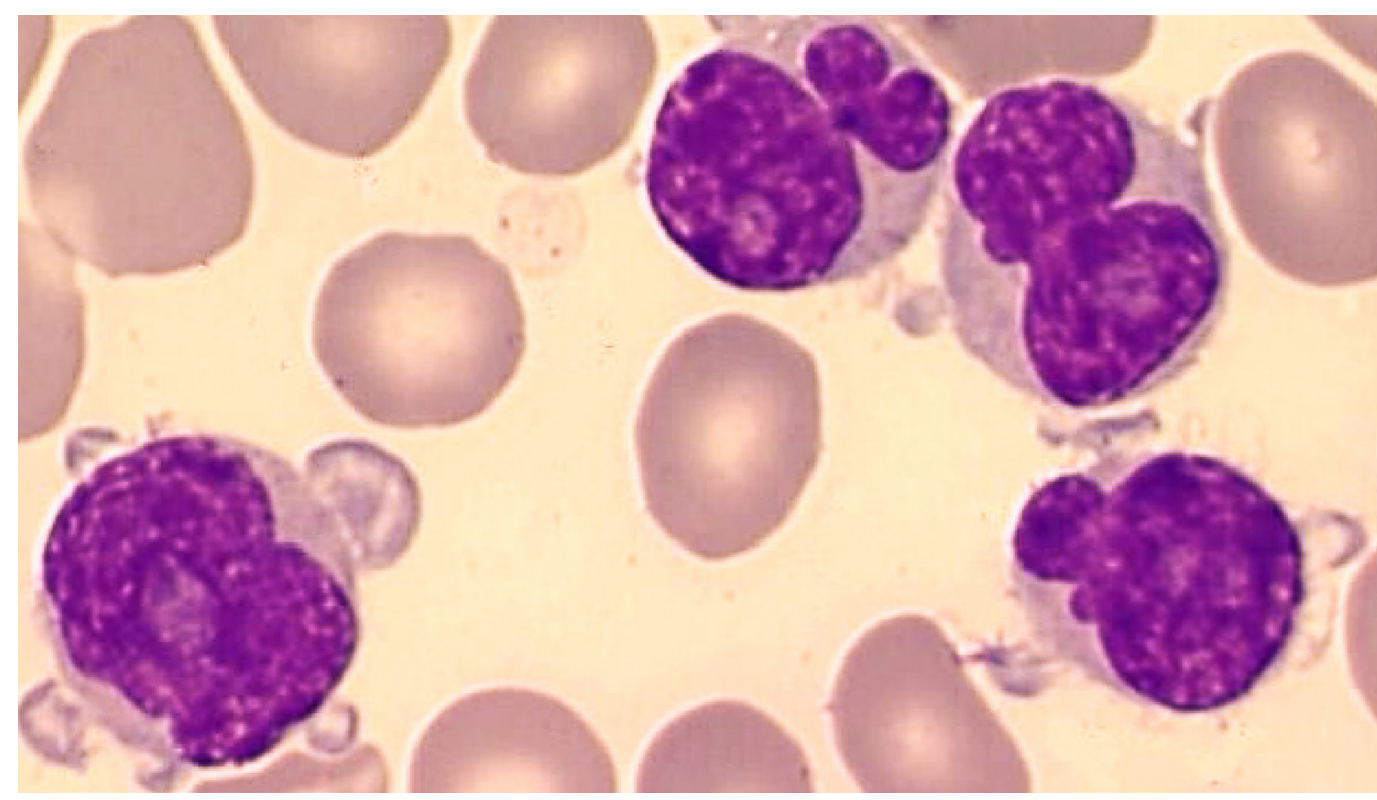

Figure 4: Small and medium-sized cells containing distinct nucleoli and very irregular nuclei (flower-like appearance): ATLL aspect (MGG, X 100).

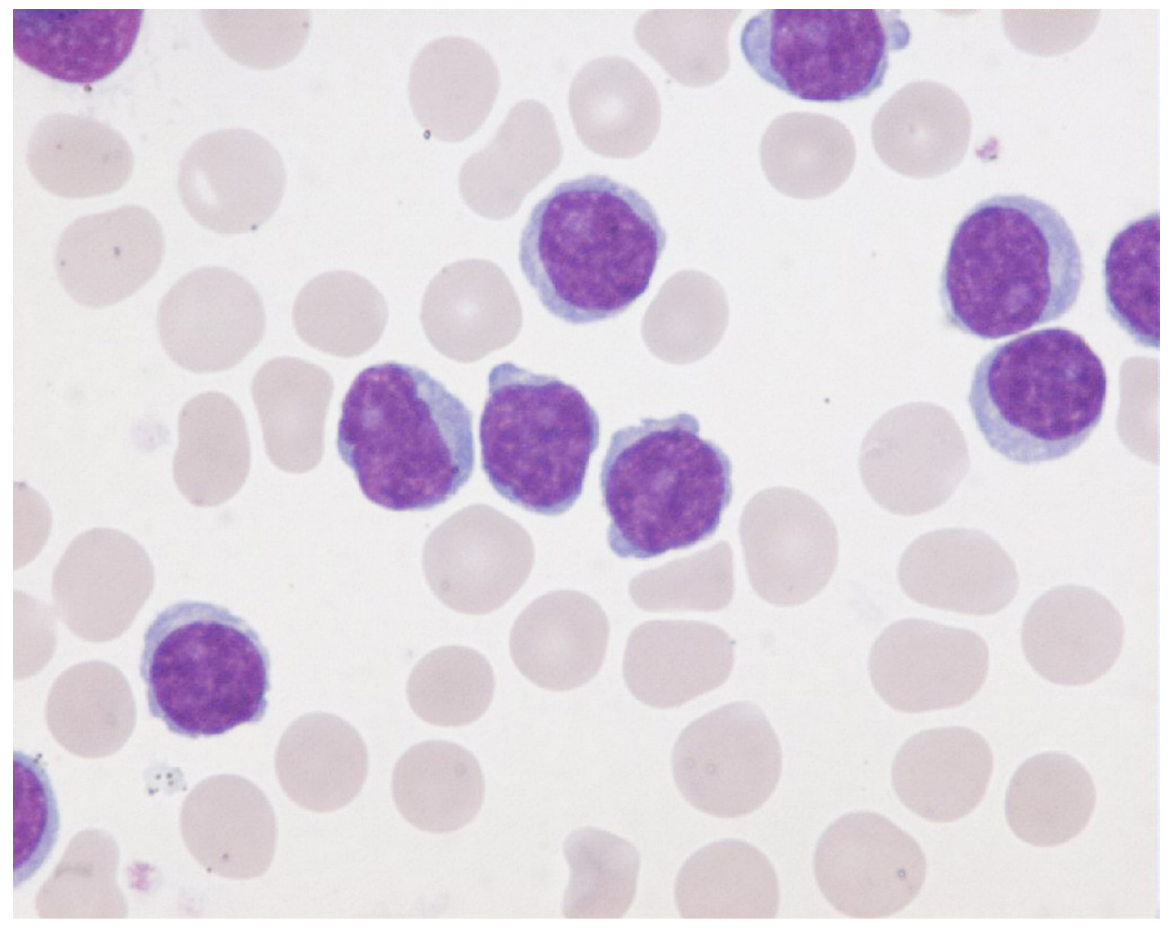

Figure 5: Small cells containing distinct nucleoli, basophilic cytoplasm, and irregular nuclei, barely distinguishable from CLL cells, except for the presence of characteristic cytoplasmic extensions (Blebs) (MGG, X 100). 
expressed in myeloid blasts, and aberrantly expressed on occasion in T-cell lymphoblastic leukemia (T-LL) [13], but has been rarely reported in T-PLL $[2,14]$.

Both cases with naïve (CD45RA+, CD45RO-) and memory (CD45RA-, CD45RO+) T-cell antigen expression have been reported $[9,15]$. The memory phenotype was associated by one group with more aggressive disease [9].

The weak surface expression of CD3 and CD45, expression of both CD4 and CD8, and high CD7 expression suggest that T-cell prolymphocytes might be at an intermediate stage of differentiation between thymic and post-thymic T cells.

This phenotypic heterogeneity is further demonstrated by the report of cases with two or more distinct abnormal subsets, with distinct expression of CD4 and CD8 [2]. Furthermore, a switch from CD4 to CD8 expression during the evolution to the more aggressive form [16] has also been reported, as well as a change in the CD4/CD8 phenotype in relapsed or progressive cases relative to that at diagnosis, with increased CD8 expression and the same clonal T-cell receptor gene rearrangement at both time points $[2,16]$. This may be related to clonal evolution on an oligoclonal background, infiltration by T-PLL cells initially present in other tissues, or potential therapeutic selection of preexisting undetected sub-clones at diagnosis.

However, even if certain morphological and phenotypic characteristics strongly suggest T-PLL, it is in some cases difficult to distinguish them from other mature T-leukemia. This issue is addressed later in the chapter devoted to differential diagnosis.

\section{Cytogenetic and molecular biology}

\section{Cytogenetics/array-based CGH}

Classical cytogenetics have revealed the presence of complex karyotypes with recurrent chromosomal abnormalities. Genes involved in cell cycle regulation, apoptosis, and DNA repair have been identified in the transcriptomes of purified T- PLL blood samples using DNA microarray technology [3, 17-28].

Recurrent genetic alterations include translocations involving either TCL1 at 14q32.1, or MTCP1 at Xq28, inactivation of the ATM gene by deletion and/or mutation, isochromosomes of chromosome 8, and haploinsufficiency of the CDKN1B gene.

Recurrent changes involving chromosome 14 are the most common genetic alteration, including inv(14) (q11q32) and $\mathrm{t}(14 ; 14)$ (q11;q32), observed in more than two thirds of cases. These rearrangements involve the TCR $\alpha$ locus in $14 \mathrm{q} 11$ and the TCL1 locus in $14 \mathrm{q} 32$ resulting in the juxtaposition of these two genes and leading to activation of the proto-oncogene TCL-1 [3, 17-19, 22-25]. TCL1 plays an essential role in the pathogenesis of T-PLL,

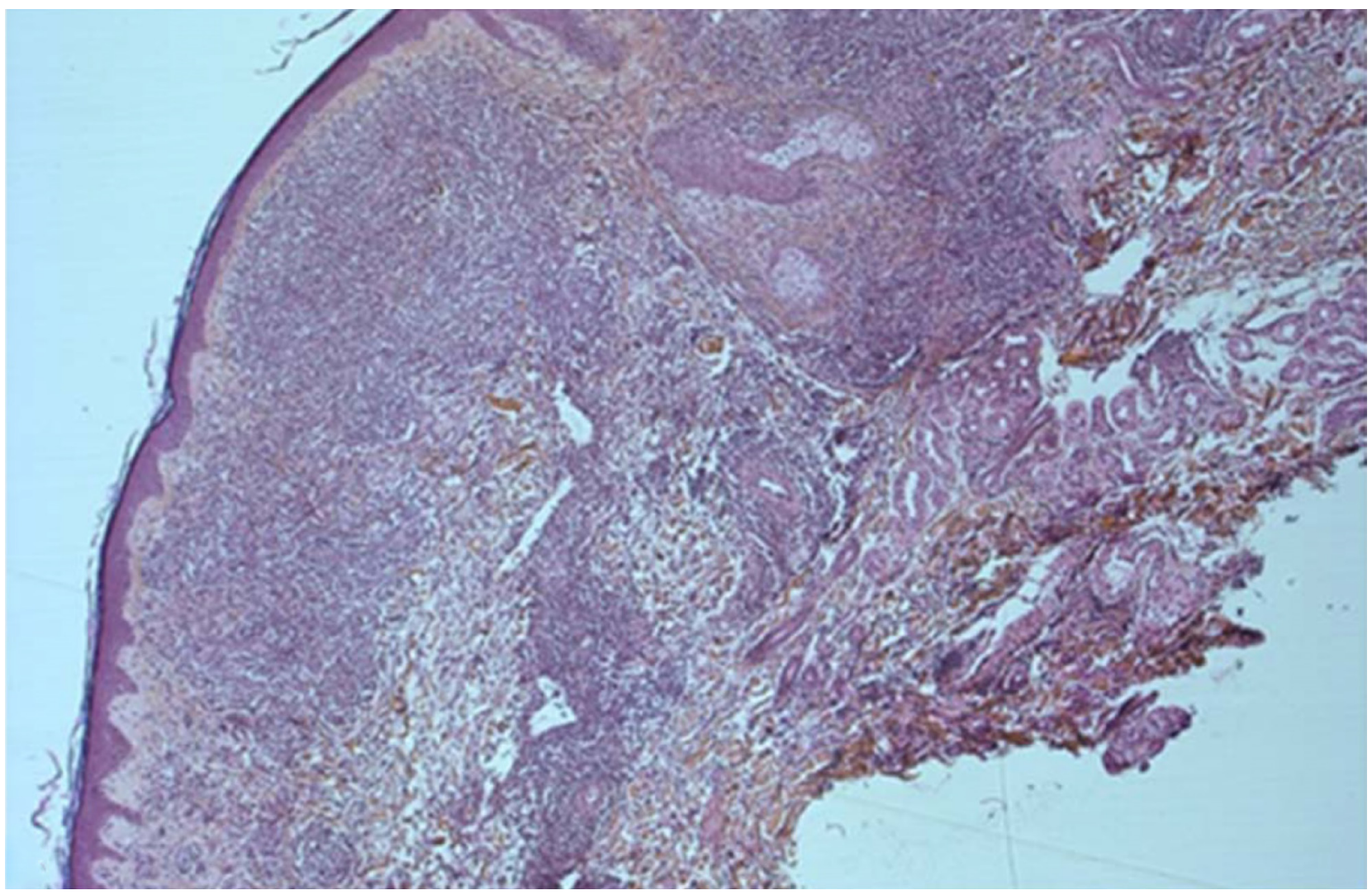

Figure 6: Dermal infiltration with perivascular and periadnexal involvement without epidermotropism (HES, X 5). 
as its overexpression leads to activation of protein kinase $\mathrm{B}$ (Akt), resulting in increased cell proliferation [20, 25-26]. TCL1 acts as a cofactor of Akt1 that enhances Akt1 kinase activity and promotes its nuclear transport [26].

TCL6, also situated in the breakpoint cluster region on $14 \mathrm{q} 32$, has been suggested to be a candidate target of $\operatorname{inv}(14)$ (q11q32.1) [27].

Approximately $20 \%$ of patients have abnormalities involving Xq28 (MTCP-1 locus), resulting from $\mathrm{t}(\mathrm{X} ; 14)$ $(\mathrm{q} 28 ; \mathrm{q} 11)$ or $\mathrm{t}(\mathrm{X} ; 7)(\mathrm{q} 28 ; \mathrm{q} 35)$. The translocation $\mathrm{t}(\mathrm{X} ; 14)$ (q28;q11), involves rearrangement of the TCR $\alpha$ locus with the proto-oncogene MTCP1 (belonging to the TCL-1 gene family) [3, 21, 24], resulting in increased cell proliferation.

Abnormalities affecting chromosome 8 have been reported in more than two-thirds of cases and consist mostly of trisomy for $8 \mathrm{q}$, resulting predominantly from an iso(8)(q10) and an increased expression of MYC, or rearrangements with $8 \mathrm{p} 12[3,17-19,22-25,29] .8 \mathrm{p}$ is known to contain various suppressor genes associated with the emergence of solid tumors [30-32], and it was suggested that the loss of a tumor suppressor gene or activation of an oncogene on $8 \mathrm{p}$ cooperates with increased dosage of the q arm and/or the expression of TCL-1/ MTCP-1 to allow the malignant phenotype to emerge [19].
The ATM protein plays a central role in the cellular response to DNA damage. Cells with deletions/ mutations of ATM are characterized by impaired apoptotic responses to DNA damaging agents. Phenotypically, ATM mutant cells exhibit impaired DNA double strand break repair [33]. Changes in 11q23 are rarely detected by cytogenetics, but molecular analysis often detects deletion and/or mutation of the ATM gene in some sporadic T-PLL cases $[26,28,34]$.

In contrast to the genetic instability expected from ATM inactivation, few non-recurrent changes have been reported, but several other recurrent chromosomal abnormalities have been associated with T-PLL neoplasms: loss at 22q11, 13q, 6q, 9p, 12p, 11p11-p14, and 17p, and gains at 8q; 22q21; 14q32; 22q21-qter, and 6p [24, 35], or co-existence of $\mathrm{t}(\mathrm{X} ; 14)(\mathrm{q} 28 ; \mathrm{q} 11), \mathrm{t}(\mathrm{Y} ; 14)(\mathrm{q} 12 ; \mathrm{q} 11)$ and a ring chromosome derivate from $\mathrm{i}(8)(\mathrm{q} 10)$ [36].

Some have suggested that gains of $8 \mathrm{q}$ result in c-MYC amplification, which directly activates the NBS gene product (NBS1 or nibrin). Overexpression of the NBS1 gene increases cell proliferation, and has a potential causal role in T-PLL progression, through the activation of the phosphatidylinositol 3-kinase/Akt signaling pathway $[28,37,38]$.

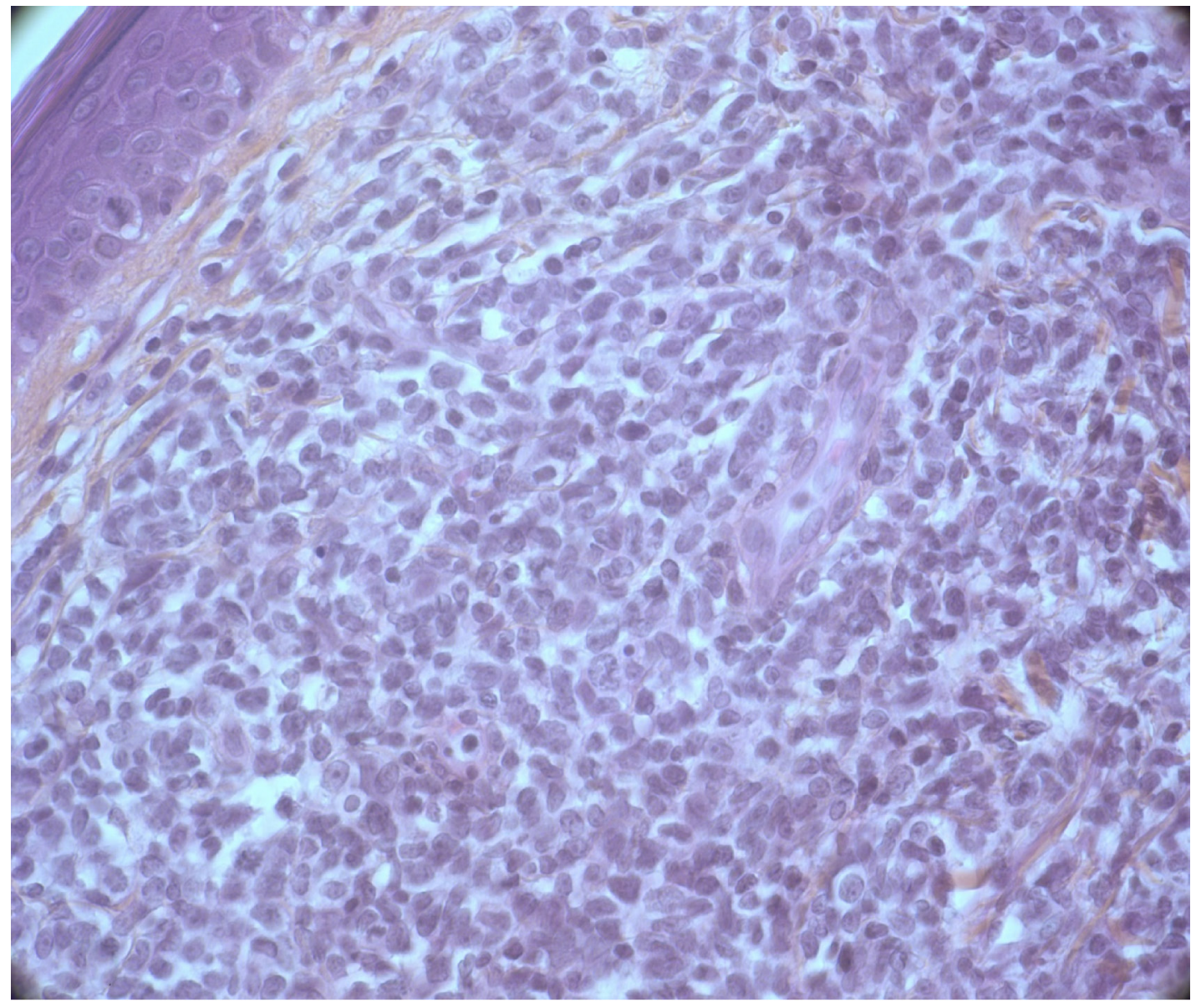

Figure 7: Dermal infiltration by medium-sized cells with irregular immature nuclei (HES, X 40). 


\section{Next generation sequencing/whole exome sequencing}

More recently, genomic sequencing studies of T-PLL have highlighted other events that affect the pathogenesis of T-PLL. Whole-genome sequencing (WGS) and wholeexome sequencing (WES), have revealed mutually exclusive mutations that affect IL2RG, JAK1, JAK3, or STAT5B in three quarters of cases, and identified mutations in recurrently altered genes involved in DNA repair, epigenetic transcriptional regulation, and proteasomal degradation, including EZH2, FBXW10, and CHEK2 [4].

JAK 1 and JAK3 belong to the Janus kinase (JAK) family of intracellular, non-receptor tyrosine kinases that transduce cytokine-mediated signals via the JAK-STAT pathway, involved in regulating the transcription of several genes [39].

Several studies have reported a high frequency of mutations in genes of the JAK- STAT pathway with gains of functions involving JAK1, JAK3, and STAT5B, not unlike those of JAK2, TYK2, and STAT3 which have been described in other mature T-cell leukemias [15, 40, 41].

The IL2RG-JAK1-JAK3-STAT5B mutations lead to elevated transcriptional activation of STAT5, and induce constitutive STAT5 hyper-phosphorylation, as well as oncogenic transformation. Inhibition of STAT5 leads to a large reduction in cell proliferation and viability of JAKmutated cell lines, and primary T-PLL patient samples bearing JAK-STAT pathway mutations [4].

MTCP1 TEL-JAK2 double transgenic mice have also been used to show oncogenic cooperation between MTCP1 and activation of the JAK-STAT pathway. MTCP1 and TEL-JAK2 transgenic mice were crossed and monitored for the onset of leukemia. MTCP1 TEL-JAK2 double transgenic mice died significantly earlier than mice of the other three genotypes. At 269 days, surviving mice were represented as follows: $100.0 \% \mathrm{WT}, 91.0 \% \mathrm{MTCP} 1,90.4 \%$ TEL-JAK2 and 6.2\% MTCP1 TEL-JAK2, $\left(p<10^{-9}\right)$ [39].

Mutations in JAK3 have been recently reported in $21-42 \%$ of T-PLL patients. The JAK $3^{\mathrm{M} 511 \mathrm{I}}$ mutant protein was found in $53-62 \%$ of cases [4, 40-42]. Another minor hotspot mutation JAK3 ${ }^{\mathrm{A} 573 \mathrm{~V}}$ was found in $12-16 \%$ of cases $[4,40]$. Mutations in JAK1 have been found in $6-10 \%$ of T-PLL [4, 40, 42].

Some patients had more than one JAK mutation, suggesting that these mutations either have additional effects or independent JAK mutations occurred in different sub-clones [4, 40, 41]. Bellanger et al. also suggested that JAK mutations may be acquired during the evolution of the disease. One patient carried a JAK1 mutation (JAK1

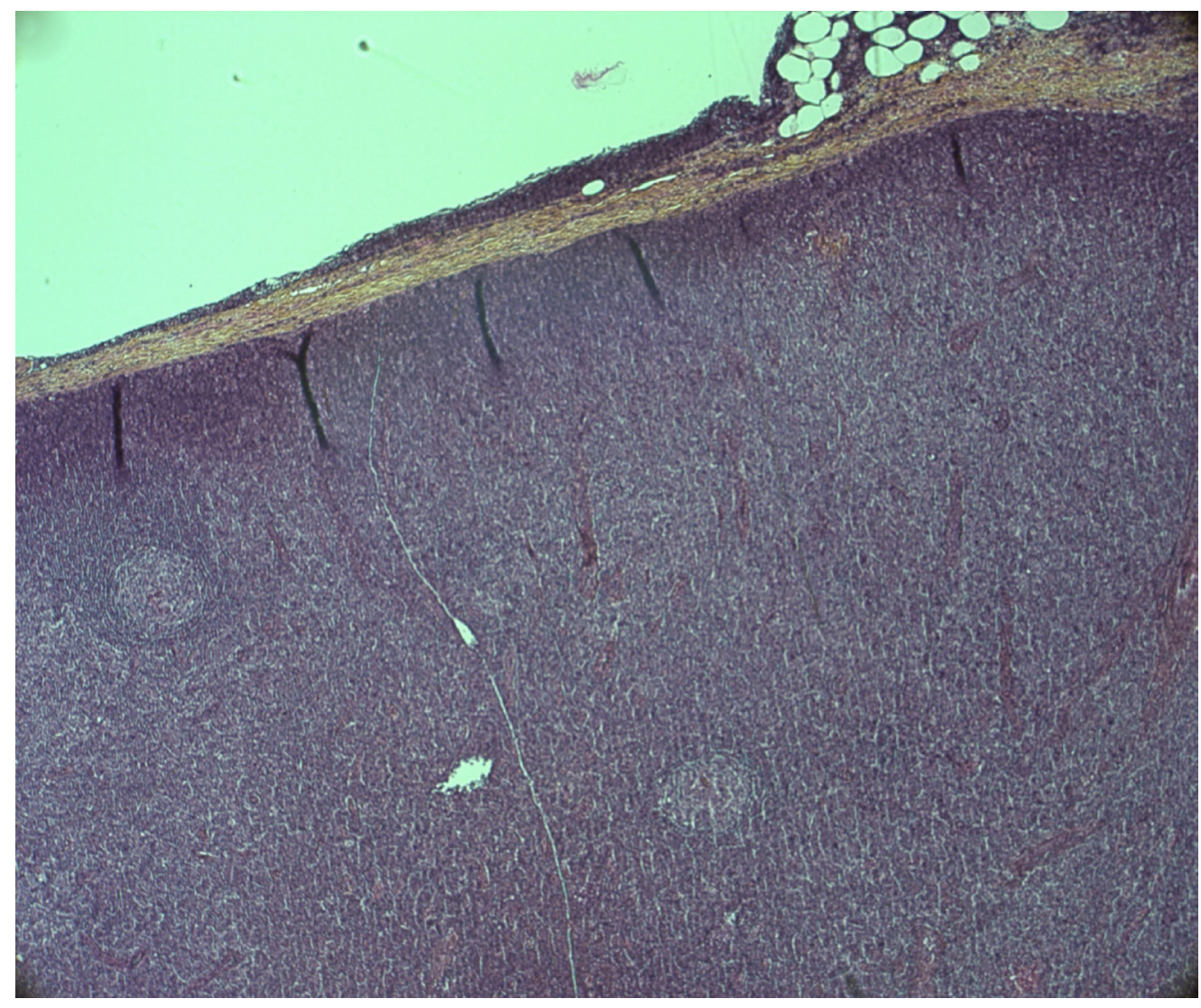

Figure 8: Diffuse lymph node infiltrate with paracortical expansion. Persistence of two residual lymphoid follicles (HES,X 5). 
c.1886_1891del) at a low level in the chromatogram, confirmed by sub-cloning. This was unexpected given the almost pure leukemic population from which the sequence was obtained [40].

Subsequent WES RNA sequencing analysis revealed somatic mutations in genes involved in DNA binding and chromatin remodeling, such as IKZF1 (N159S) and HDAC8 (I115R), or the kinase signal pathway such as NTRK1 (R33W), TNIP2 (K104Q), VAV3 (C282Y and splice site mutation), EML4 (L548W and F304S), AP2A2 (P514L), and RARB (G90W). RNA sequencing also revealed several fusion transcripts resulting in early stops of several different genes including PTPRT, L3MBTL1, and UCKL1 [15].

Next generation amplicon deep-sequencing has been performed to analyze potential mutations in the ATM, BCOR (BCL6 corepressor), and TP53 genes. The ATM gene had the highest frequency of mutations (73\%), whereas the mutation frequency was much lower for the TP53 (14\%) and BCOR (8\%) genes [42].

The same team studied the correlation between cytogenetic aberrations and molecular mutations, and identified two distinct genetic subgroups: The first subgroup, representing $86 \%$ of cases, showed abnormalities involving the TCRA/D locus, with higher frequencies of $\mathrm{i}(8)(\mathrm{q} 10)$ and ATM mutations, whereas the second subgroup, including the remaining 14\%, was characterized by the lack of a TCRA/D rearrangement, rare cases of $\mathrm{i}(8)(\mathrm{q} 10)$, and a higher frequency of TP53 mutations. The TP53 mutated subgroup was found mostly in samples from older patients (albeit not statistically significant), whereas T-PLL in younger patients was essentially characterized by translocations involving the TCRA/D locus [42].

Deletions in 12 p13 that lead to haplo-insufficiency of the CDKN1B gene have been suggested to play a role in the pathogenesis of T-PLL, as this gene encodes the cyclin-dependent kinase inhibitory protein p27 (KIP1), which functions in cell-cycle regulation $[43,44]$.

Recently, Lopez et al. reported mutations in a subset of 23 T-PLL cases in the genes encoding the epigenetic regulators EZH2 in 13\% (3/23), TET2 in 17\% (4/23), and BCOR in $9 \%(2 / 23)$ of the cases [45].

Recently, Zhang et al performed whole exome sequencing and transcriptomes in a series of 12 T-PLL samples and reported mutations in $\mathrm{NOTCH}$ and altered of Wnt/ $\beta$-Catenin pathways, indicate dysregulated embryonic developmental in the pathogenesis of T-PLL. They identified novel (KDM6A and KDM6B) and previously reported mutations (ATM, TET2) in chromatin regulatory genes, emphasizing the importance of epigenetic dysregulation in the pathogenesis of T-PLL [46].

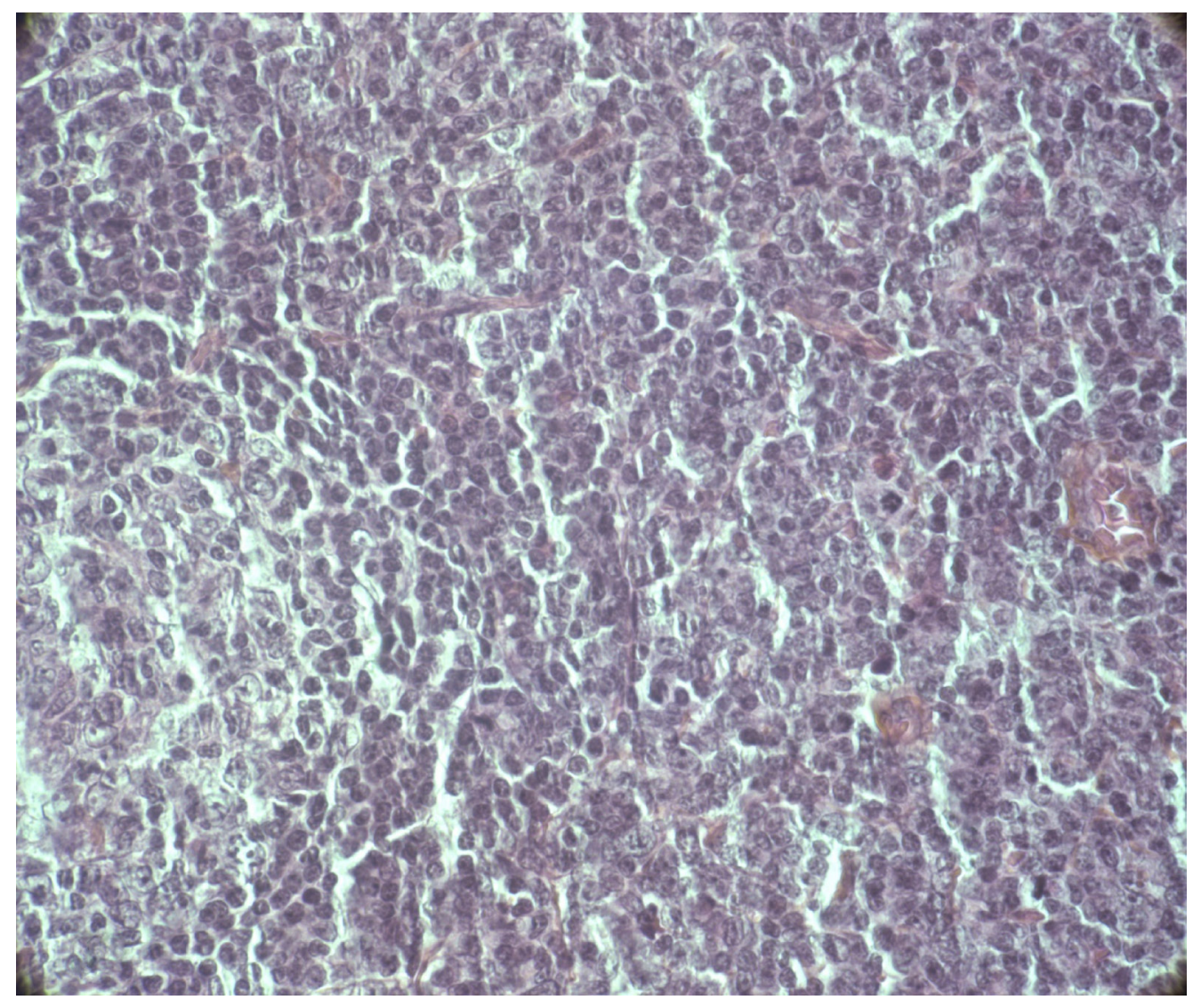

Figure 9: Lymph node infiltrate by medium-sized cells with irregular nuclei (HES, X 40). 
The last several years have witnessed an acceleration of our understanding of the mechanisms involved in the pathogenesis of this disease, with the identification of novel mutations and oncogenic cooperation, which will open the way for targeted therapies.

\section{Clinical aspects}

T-PLL is a rare disease accounting for $2 \%$ of mature lymphocytic leukemias and approximately $20 \%$ of PLL. Within mature T -cell leukemia, T- PLL may represent up to $40 \%$ of cases. This is a disease of older adults with a median age at presentation of 65 years [47], and occurs more frequently in males (male:female $=2: 1$ ) $[1,47]$. Patients typically present with aggressive, widely disseminated disease at diagnosis, and a poor outcome. In a minority of cases, indolent forms can preexist at diagnosis, usually evolving to a more aggressive form [9]. In T-PLL, the white cell count is usually $>100 \times 10^{9} / \mathrm{L}$ at presentation, as in B-PLL. Otherwise, most patients present with splenomegaly, lymphadenopathy, hepatomegaly, and skin lesions which include skin nodules, a maculopapular rash, or more rarely, erythroderma (Table 2) [1, 5, 9, 48, 49]. Peripheral edema, particularly periorbital and/or conjunctival, occurs relatively frequently and seems to be particularly characteristic of T-PLL. Pleural or peritoneal effusions also sometimes occur. Other extra-nodal sites [50], which may be seen at presentation or during evolution, include the central nervous system (CNS).

\section{Differential diagnosis}

Differential diagnosis of T-PLL often occurs with other mature T-cell leukemias including T-cell large granular lymphocytic leukemia (T-LGLL), Sézary syndrome (SS), and adult T-cell leukemia/ lymphoma (ATLL). These disorders are characterized by heterogeneous clinical manifestations and outcome.

T-LGLL is an indolent clonal proliferation of cytotoxic T-cells. Patients are either asymptomatic, or present signs related to T-LGLL-induced cytopenia and associated with autoimmune disorders [51-53]. However, aggressive variants have been described with marked lymphocytosis, lymph-node infiltration, and hepatosplenomegaly [54-57]. T-LGLL cells in most cases have characteristic morphological features: large lymphocytes with abundant cytoplasm and fine or coarse azurophilic granules, which distinguish them from T-PLLs. However, in rare cases they do not display this typical morphology. In most cases, T-LGLL exhibits a constitutive mature post-thymic phenotype including CD3+, TCR $\alpha \beta+$, CD4-, CD5dim, CD7dim, CD8+, CD16+, CD27-, CD28-, CD45R0-, CD45RA+ and CD57+ characteristic of a constitutively activated T-cell phenotype $[52,53]$. The less frequent CD3+CD56+ variant is associated with the most aggressive behavior [54-56]. In rare cases, T-LGLL exhibits a CD4+ phenotype with or without co-expression of CD8, associated with a significantly lower frequency of cytopenia, and of other associated autoimmune diseases $[58,59]$. Cytogenetic abnormalities in T-LGLL have rarely been reported, in contrast to T-PLL, and there is no unique karyotypic abnormality [57, 60].

Sézary syndrome (SS) is an aggressive form of cutaneous T-cell lymphoma characterized by generalized erythroderma, peripheral blood involvement (frequently with PB eosinophilia) and generalized lymphadenopathy. The circulating neoplastic T-cells cells exhibit a distinct cerebriform morphology (and are called Sézary cells). The three main variants of SS are: primary SS (or Sézary leukemia) in which leukemia is present initially with erythroderma; SS arising in a setting of Mycosis Fungoides (MF); and SS that develops in the context of idiopathic erythroderma [61-63].

SS phenotypes are diverse but the tumor cells are typically T-helper memory lymphocytes, which are CD3+, CD4+ and CD5+. The neoplastic cells in SS express TCR $\alpha \beta$ and have variable loss of expression of surface markers such as CD2, CD3, CD5, CD7 and CD26 [64-67]. In rare cases, SS cells express a CD8+ phenotype, and some exhibit a CD4-CD8- null phenotype [68]. Likewise, double CD4+ CD8+ is very rare, and should prompt a consideration of T-cell prolymphocytic leukemia [69].

Chromosomal abnormalities include gain of 17p11.2-q25.3 and 8q24.1-8q24.3 and loss of 17p13.2-p11.2; 10p12.1-q26.3, which are each observed in $>40 \%$ of SS. Duplication of $17 q 11.2$ approximately q12 duplication is common to both MF and SS, which suggests that this is an early clonal event $[70,71]$ Gains of TCRB and TCRG, loss at least one copy of BCL2, gains of c-MYC and loss of c-MYC antagonists (MXI1and MNT) have also been reported [72-74].

Adult T-cell leukemia/lymphoma is a rare mature T-cell neoplasm associated with the retrovirus human T lymphotrophic virus type 1 (HTLV-1). Patients with aggressive ATL generally have a poor prognosis with a large tumor burden, hypercalcemia, frequent infectious complications due to profound T-cell immunodeficiency, and multi-organ failure. ATLL cells exhibits characteristic lymphocytes with a "flower cell" aspect, and express a mature T-cell phenotype: CD2+, CD3+, CD4+, CD8-, CD25+, CD7, $\mathrm{CD} 5+, \mathrm{CD} 25+$ (strong and uniform), CD29+, CD45RO+, TCR $\alpha \beta+$, and HLA-DR+. There is aberrant loss of CD7 and CD26, and often downregulation of CD3 [75-77]. CD25 expression may be distinctive but not specific, because is also expressed in T-PLL and Sézary syndrome. ATLL with double-positive $\mathrm{T}$ cells (CD4+, CD8+) and only CD8+T lymphocytes have also been described [75-79].

Karyotypic abnormalities revealed by conventional cytogenetics or comparative genomic hybridization are complex, particularly in the acute forms, although there is no apparent characteristic abnormality; the abnormalities include aneuploidy $(+3,+7,+21,-\mathrm{X},-\mathrm{Y})$, abnormalities 
Table 2: Clinical characteristics of T-PLL in previously reported series

\begin{tabular}{|c|c|c|c|c|c|}
\hline & Matutes (1) & Matutes (5) & Garand $(9)^{\mathrm{a}}$ & Garand $(9)^{b}$ & Ravandy (48) \\
\hline Number of patients & 78 & 29 & 53 & 25 & 57 \\
\hline Age (y) median & 69 & 69 & 69 & 72 & 63 \\
\hline B symptoms & & & 66 & 11 & \\
\hline Splenomegaly (\%) & 73 & 82 & 81 & 11 & 42 \\
\hline Lymphadenopathy (\%) & 53 & 46 & $64^{*} / 28^{* *}$ & 0 & 47 \\
\hline Hepatomegaly (\%) & 40 & 42 & 43 & 5 & 24 \\
\hline Skin lesions $(\%)$ & 27 & 25 & 25 & 0 & \\
\hline Serous effusions (\%) & 14 & 21 & 19 & 0 & \\
\hline Other extra-nodal site (\%) & & & 13 & 0 & \\
\hline WBC $\left(>100 \times 10^{9} / \mathrm{L}(\%)\right.$ & 75 & 82 & 70 & 0 & \\
\hline WBC: $100 \times 10^{9} / \mathrm{L}($ median $)$ & & & 164 & 19 & 144 \\
\hline Hemoglobin < $10 \mathrm{~g} / \mathrm{dl}(\%)$ & 36 & 55 & 15 & 0 & \\
\hline Hemoglobin: g/dl (median) & & & & & 11.8 \\
\hline Platelets $<100 \times 10^{9} / 1(\%)$ & 51 & 68 & 36 & 10 & \\
\hline Platelets: $100 \times 10^{9} / 1($ median $)$ & & & & & 85 \\
\hline
\end{tabular}

${ }^{\text {a}}$ Aggressive forms, ${ }^{\text {b Indolent forms, }}$ "Peripheral lymphadenopathy, ${ }^{* *}$ Abdominal or hilar lymphadenopathy, which will open the way for targeted therapies

of $3 p$, and translocations involving $14 q 11$ and $14 q 32$ sites of TCR(alpha) and TCR(delta) genes, respectively [76, 80, 81].

More sensitive array-comparative genomic hybridization showed that the lymphoma subtype is significantly more frequently associated with gains at $1 \mathrm{q}$, $2 \mathrm{p}, 4 \mathrm{q}, 7 \mathrm{p}$, and $7 \mathrm{q}$ and losses of 10p, 13q, 16q, and 18p, whereas the acute subtype showed a gain of 3/3p [82]. Differential diagnosis with T-PLL could occur in endemic area but rarely in the USA or Europe.

Several studies have suggested that some cases of mature T-leukemia may overlap morphologically and phenotypically with T-PLL. Pawson et al. reported nine cases of mature $\mathrm{T}$ cell disorder with morphological similarities to Sézary cells, but clinical and laboratory features were different from those seen in SS: lymphocytosis was between 12.7 to $133 \times 10^{9}$, bone marrow infiltration, splenomegaly, lymphadenopathy, hepatomegaly, and CNS involvement in some cases; there was no skin involvement at diagnosis but this developed as a terminal event in two patients, one of whom presented a lymphoid infiltrate in the dermis, unlike the epidermotropism characteristic of SS. The cells from eight cases exhibit a mature $\mathrm{T}$ cell phenotype: TdT, CD1a-, CD2+/-, CD3+, CD5+, CD25-. In three cases, the cells co-expressed $\mathrm{CD} 4+$ and $\mathrm{CD} 8+$, in two cases they were $\mathrm{CD} 4-\mathrm{CD} 8+$, in one case were $\mathrm{CD} 4+\mathrm{CD} 8-$, and in two cases the cells had a CD4-CD8- null phenotype. The CD7 antigen was expressed in six cases. One case was HTLV-1 serology positive and the diagnosis of adult $\mathrm{T}$ cell leukemia/lymphoma could not be excluded. Cytogenetic analysis of three cases revealed complex chromosomal abnormalities: in two cases, both isochromosome 8q and inversion 14(q11; q32) were found and in one case, $\mathrm{t}(\mathrm{X} ; 14)(\mathrm{q} 28 ; \mathrm{q} 11)$ was detected. One patient showed complete remission of 21 months' duration after treatment with Campath-1H. The median survival for the nine cases was 13 months. These observations suggest substantial similarity between Sézary cell leukemia or primary SS and some T-PLL cases. Cytogenetic investigations may help to distinguish them by identifying chromosomal abnormalities involving either TCL1 at $14 \mathrm{q} 32.1$, or MTCP1 at Xq28 in T-PLL [83].

Brito-Babapulle et al. explored the relationship between T leukemia with cerebriform nuclei and T-PLL. They performed a cytogenetic analysis with in situ hybridization of three cases with SS, and three cases with Sézary cell leukemia. Patients with SS had generalized erythroderma as expected, whereas patients with Sézary cell leukemia did not display apparent clinical skin involvement. All six cases had a mature T-cell phenotype, CD2+, CD3+, CD5+, and were CD1a-, CD11b-, CD16-, CD56-, CD57-. The three SS cases exhibited a CD4+CD8phenotype, whereas all three Sézary cell leukemia cases co-expressed CD4 and CD8. All three cases with Sézary cell leukemia had inv (14)(q11;q32) and two had iso 8q, supporting the classification as a cerebriform variant of T-PLL. In contrast, SS cells did not show these abnormalities, but all three cases had iso (17q) or $17 p^{+}$ abnormalities. One case of Sézary cell leukemia had iso (17q). These finding suggest that Sézary cell leukemia may be a variant of T-PLL rather than of SS [84].

Kussick et al. reported two cases of mature $\mathrm{T}$ cell lymphoproliferative disorder with cells exhibiting a $\mathrm{CD} 3+, \mathrm{CD} 4+$ phenotype, without clinical 
or morphological features suggesting either T-PLL (absence of the prolymphocytoid morphology, and of associated hepatosplenomegaly and/or generalized lymphadenopathy), or MF/SS, ATLL, T-LGLL or an underlying peripheral $\mathrm{T}$ cell lymphoma. Cytogenetic investigations were uninformative for diagnosis: findings were normal in one case and such tests not performed in the second case [85].

Herling et al. analyzed 102 cases of mature T-cell leukemia (38 T-PLL, 32 primary SS, 17 secondary SS, and 15 T-LGLL cases) and compared them to 10 cases of hepatosplenic lymphomas (HSTCL) that involved peripheral blood. The T-PLL cases showed rapidly rising PB lymphocyte counts with median peaks at $171.3 \times 109 / \mathrm{L}$; the corresponding values were while it was $5.9 \times 10^{9} / \mathrm{L}$ for in primary SS, $5.7 \times 10^{9} / \mathrm{L}$ for secondary SS, and $3.6 \times 10^{9} / \mathrm{L}$ for T-LGL leukemia cases. Some T-PLL cases had relatively low lymphocyte counts, and some primary SS and T-LGL leukemia cases had higher lymphocyte counts. T-PLL cases showed heterogeneous morphology, but SS cases exhibited the greatest variability including cells with large prolymphocytoid forms. CD4+CD8-, CD4+CD8+, CD4CD8+, and CD4-CD8-phenotypes were found in 63\%, 32\%, $5 \%$, and $0 \%$ of cases of T-PLL, respectively. CD4+CD8-, CD4+CD8+, CD4-CD8+, and CD4-CD8- phenotypes were observed in $94 \%, 3 \%, 0 \%$, and $3 \%$ of primary SS cases, respectively, and in $13 \%, 0 \%, 87 \%$, and $0 \%$ of T-LGL leukemia cases, respectively.

All cases of T-PLL and primary SS showed CD5 expression, whereas $75 \%$ of T-LGL leukemia cases were negative or only weakly positive for CD5. CD7 was expressed in $95 \%$ of tumor cells of T-PLL cases tested, but in only $61 \%$ of primary SS, $47 \%$ of secondary SS, $77 \%$ of T-LGL, and $67 \%$ of HSTCL of cases tested. Expression of CD26 was observed in 77\% of T-PLL cases tested, but was less frequent in T-LGL $(18 \%)$, primary SS $(3 \%)$, secondary SS (18\%), and HSTCL (0 of 3 tested) cases. TCR- $\gamma \delta$ was expressed in $60 \%$ of HSTCL cases, only $14 \%$ of T-LGL leukemia cases, and no T-PLL or SS case.

TCL1 was expressed in 77\% (10/13) of T-PLL cases tested by western blotting, and in 71\% (27/38) of cases analyzed by immunostaining on paraffin sections; TCL1 expression was not detected in any primary SS, secondary SS, T-LGL, or HSTCL cases tested.

These findings reveal a degree of overlap between the features of T-PLL cases and those of other mature T-leukemias, especially primary SS. Nevertheless, some clinical and biological characteristics are more prevalent in some of these diseases than others. For example, rapidly rising and high peak PB lymphocyte counts, hepatosplenomegaly, presence of effusions and TCL1 expression are more frequently associated with T-PLL. Generalized erythroderma, PB eosinophilia, and lymphadenopathy are more typical of SS, and the presence of multiple cytopenias especially neutropenia and autoimmune disorders is most common in cases of T-LGLL [86].
More rarely, there is overlap with some HSCTL or other nodal lymphomas with PB involvement. Nevertheless, these diseases can generally be distinguished on the basis of TCR $\gamma \delta$ rearrangement, pronounced hepatosplenomegaly and sinusoidal $\mathrm{BM}$ infiltration for HSCTL, or predominant nodal presentation and the pattern of lymph node infiltration for nodal lymphomas with PB involvement.

\section{Prognostic factors}

In the series of the Royal Madsen Hospital, patients with serous effusions and hepatic or CNS involvement, or very bulky lymph node masses also had a poor response to therapy [87].

Age, gender, and race were not significant predictors of survival in a total of 272 cases of T-PLL studied between 1994-2010 based on multivariate analysis of the Surveillance Epidemiology and End Results (SEER-18) database. The median survival for the entire cohort was 21 months. A significant improvement in OS was noted for patients diagnosed after FDA approval of alemtuzumab (26 versus seven months) [88].

In a series from the MD Anderson Cancer Center, poor outcome was associated with age $>65$ years, WBC over $40 \times 10^{9} / \mathrm{L}$ at diagnosis, short lymphocyte doubling time, and high expression of the TCL-1 protein measured by flow cytometry and immunohistochemistry [20].

Bergmann et al reported that JAK3 mutations have a significant adverse impact on OS [41].

More recently, Aoki et al. reported that pleural effusion, a high absolute lymphocyte count, and a complex karyotype predicted an increased risk of death in 43 untreated patients among a series of 101 T-PLL cases [89].

However, these data are all derived from a small number of patients and do not allow us to determine the prognostic factors at diagnosis with certainty, or the indolent course of certain forms and their switch to the aggressive form.

\section{Therapeutic options}

Alemtuzumab currently remains the first line treatment for T-PLL. It has improved the median OS obtained with alkylating agents or various purine analogues (Table 3). Despite a high response rate that can exceed 90\% (Table 4), most patients who do not receive treatment intensification with allogeneic bone marrow transplantation will relapse with a median survival of 17-33 months in patients achieving a complete response (CR) [1, 20, 48-50, 87-92], increasing to 48 months after consolidation with autologous or allogeneic stem cell transplantation [93] (Table 5).

New treatment options are needed because of the high median age of most of the patients, associated comorbidities, and their impossibility to receive allogeneic bone marrow transplantation. 
Table 3: Conventional chemotherapy in patients with T-PLL

\begin{tabular}{|c|c|c|c|c|}
\hline & $N$ & ORR (\%) & CR (\%) & Median OS (months) \\
\hline alkylating agents (1) & 32 & 31 & 3 & $7.5^{\mathrm{a}}$ \\
\hline Pentostatin $(90)^{\mathrm{b}}$ & 55 & 45 & 9 & $17.5 / 9^{c}$ \\
\hline Pentostatin $(91)^{\mathrm{d}}$ & 25 & 8 & 0 & 4 \\
\hline Bendamustine $(102)^{\mathrm{b}}$ & 15 & 53.3 & 20 & 8.7 \\
\hline
\end{tabular}

${ }^{a}$ median OS of the entire group of 78 patients treated by various therapies, ${ }^{b}$ relapsed/refractory and treatment-naïve patients,

${ }^{\mathrm{c}}$ median OS: 17.5 months for responders and 9 months for non-responders, ${ }^{\mathrm{d}}$ relapsed/refractory patients.

Table 4: Alemtuzumab-based therapy in patients with T-PLL

\begin{tabular}{|c|c|c|c|c|c|c|c|}
\hline & $\boldsymbol{N}$ & $\begin{array}{c}\text { ORR } \\
(\%)\end{array}$ & CR (\%) & $\begin{array}{l}\text { Median DOR } \\
\text { (months) }\end{array}$ & $\begin{array}{c}\text { Median DFS } \\
\text { (months) }\end{array}$ & $\begin{array}{l}\text { Median PFS } \\
\text { (months) }\end{array}$ & $\begin{array}{l}\text { Median OS } \\
\text { (months) }\end{array}$ \\
\hline $\begin{array}{l}\text { Relapsed/refractory } \\
\text { IV (98) }\end{array}$ & 15 & 73 & 60 & & & & \\
\hline $\begin{array}{l}\text { Relapsed/refractory } \\
\text { IV (87) }\end{array}$ & 39 & 76 & 60 & & 7 & & 10 \\
\hline $\begin{array}{l}\text { Relapsed/refractory } \\
\text { IV (99) }\end{array}$ & 76 & 51 & 39.5 & 8.7 & & & 7.5 \\
\hline $\begin{array}{l}\text { Relapsed/refractory } \\
\text { IV (100) }\end{array}$ & 45 & 74 & 60 & & & $26 \%$ at 12 months & $18 \%$ at 48 months \\
\hline $\begin{array}{l}\text { Subcutaneous first- } \\
\text { line }(100)\end{array}$ & 9 & 33 & 33 & & & $67 \%$ at 12 months & $33 \%$ at 48 months \\
\hline $\begin{array}{l}\text { Intravenous first- } \\
\text { line }(100)\end{array}$ & 32 & 91 & 81 & & & $67 \%$ at 12 months & $37 \%$ at 48 months \\
\hline $\begin{array}{l}\text { Intravenous in } \\
\text { association with } \\
\text { FCM }(92)^{\mathrm{b}}\end{array}$ & 25 & 92 & 48 & & & 11.9 & 17.1 \\
\hline $\begin{array}{l}\text { Intravenous in } \\
\text { association with } \\
\text { pentostatin }(101)^{\mathrm{c}}\end{array}$ & 13 & 69 & 62 & & & 7.8 & 10.2 \\
\hline
\end{tabular}

${ }^{a}$ including SCT if applicable, ${ }^{b}$ previously treated (n: 9) and treatment-naïve (n: 16), ${ }^{c}$ previously treated (n: 8) and treatmentnaïve (n: 5)

\section{Conventional chemotherapy}

\section{Alkylating agents and purine analogues}

A study of conventional chemotherapy was performed on a large series of 78 patients who received various therapies including radiotherapy or no treatment. Of the 32 patients who received alkylating agents, nine $(28 \%)$ had partial-responses (PRs). Five of 15 patients (33\%) responded to CHOP, including one CR. Among the patients who received a regimen of the adenosine deaminase inhibitor, 2-deoxycoformycin (DFC, pentostatin), 31 were evaluable. Fifteen (48.4\%) responded with three CRs and 12 PRs. The median survival for the entire group was 7.5 months. The median survival for patients treated with pentostatin (10 months) was better than for the remainder of the cohort (seven months), but was not statistically significant. Patients who responded to pentostatin had a median survival of 16 months, whereas that of non-responders was 10 months. The effect of hepatomegaly and age on survival was statistically significant [1].

The pentostatin regimen was tested in a series of 145 patients with post-thymic T-cell malignancies, among them 55 with T-PLL. Pentostatin was administered intravenously (IV), at $4 \mathrm{mg} / \mathrm{m}^{2} /$ week for the first four weeks and then every two weeks until maximal response; the last 30 patients received weekly injections until maximal response. Among the patients, $67 \%$ had received previous systemic treatment. The ORR was $45 \%$ with CRs in $9 \%$ of cases. The median delay to remission was 6 months. Toxicity was low and pentostatin was generally well-tolerated. The median duration of survival from the start of therapy with pentostatin was longer in the 
Table 5: Stem cell transplantation in patients with T-PLL

\begin{tabular}{|c|c|c|c|c|c|c|c|c|}
\hline & $N$ & $\begin{array}{c}\text { CR rate } \\
\text { before } \\
\text { SCT } \\
(\%)\end{array}$ & $\begin{array}{c}\text { CR rate } \\
\text { after } \\
\text { SCT } \\
(\%)\end{array}$ & $\begin{array}{c}\text { TRM } \\
\text { rate } \\
(\%)\end{array}$ & $\begin{array}{l}\text { Relapse } \\
\text { rate }(\%)\end{array}$ & $\begin{array}{c}\text { Median } \\
\text { DFS } \\
\text { (months) }\end{array}$ & $\begin{array}{l}\text { Median PFS } \\
\text { (months) }\end{array}$ & $\begin{array}{l}\text { Median OS } \\
\text { (months) }\end{array}$ \\
\hline $\begin{array}{l}\text { alemtuzumab+ auto- } \\
\text { SCT ( 93) }\end{array}$ & 15 & 86 & 100 & 7 & 60 & & & 52 \\
\hline $\begin{array}{l}\text { alemtuzumab+allo- } \\
\text { SCT (93) }\end{array}$ & 13 & 69 & 92 & 31 & 33 & 24 & & 33 \\
\hline $\begin{array}{l}\text { Various therapy a } \\
\text { +allo-SCT (109) }\end{array}$ & 41 & 27 & & $\begin{array}{l}41 \% \text { at } \\
3 \text { years }\end{array}$ & $\begin{array}{c}41 \% \text { at } 3 \\
\text { years }\end{array}$ & $\begin{array}{c}19 \% \text { at } 3 \\
\text { years }\end{array}$ & & $21 \%$ at 3 years \\
\hline $\begin{array}{l}\text { Various therapy } \\
+ \text { allo-SCT (110) }\end{array}$ & 21 & & & & & & 5.1 & $11.2^{\mathrm{c}}$ \\
\hline $\begin{array}{l}\text { Various therapy }{ }^{b} \\
+ \text { allo-SCT (111) }\end{array}$ & 27 & 52 & 78 & $\begin{array}{l}31 \% \text { at } \\
3 \text { years }\end{array}$ & 47 & & $\begin{array}{c}26 \% \text { at } 3 \\
\text { years }\end{array}$ & $36 \%$ at 3 years \\
\hline
\end{tabular}

${ }^{\text {a }} 24 \%$ of patients received alemtuzumab before allo-SCT, ${ }^{b} 52 \%$ of patients received alemtuzumab before allo-SCT, ${ }^{\mathrm{c}}$ median OS for the entire cohort of $47 \mathrm{~B}$ and T-PLL

responders (17.5 months) than in the non-responders $(9$ months) but did not reached statistical significance. No significant differences were observed when the results were analyzed according to previous treatment [90].

In a phase II trial, the EORTC group investigated the safety and efficacy of pentostatin in 92 cases of $\mathrm{T}$ lymphoid malignancies, including 25 evaluable T-PLL. All patients had relapsed/refractory disease: $76 \%$ had received $\leq 1$ prior chemotherapy regimens and $24 \%$ had received $\geq 2$. Pentostatin was administered at $4 \mathrm{mg} / \mathrm{m}^{2}$ every week for the first three weeks, then $4 \mathrm{mg} / \mathrm{m}^{2}$ every 14 days for another six weeks, followed by maintenance therapy. No $\mathrm{CR}$ was obtained and the PR rate was $8 \%$. The diseasefree survival rate and OS rates were 22 and 17.8 weeks, respectively [91].

Nelarabine is an arabinosylguanine nucleotide triphosphate (araGTP), a type of purine nucleoside analog, which inhibits DNA synthesis, causing cytotoxicity. Pre-clinical studies suggested that the drug was highly effective in immature T-cell diseases and, as expected, nelarabine showed significant cytotoxic activity against malignant $\mathrm{T}$ cell diseases in adult and pediatric populations $[94,95]$. On the basis of the clinical results, nelarabine was approved by the FDA and the European Union for acute lymphoblastic leukemia and T-cell lymphoblastic lymphoma that has not responded to treatment or has relapsed following treatment with at least two chemotherapy regimens [96].

Nelarabine was evaluated in a phase I trial in 35 patients with progressive and advanced leukemia, including 11 with T-PLL, using three different protocols (consecutively for five days; on days 1, 3, and 5; or on days 1,3 , and 5 in association with fludarabine). Responses were achieved in 20\% (CR: 0\%), 15\% (CR: 5\%), and 63\% (CR: 13\%) of patients, respectively. The histology, number of prior therapies, and fludarabine refractoriness status did not influence the response rate. Responses were durable, with a median time to treatment failure of 17 months in responders. The most common non-hematological toxicity was peripheral neuropathy in $21 \%$ of patients. Grade 4 neutropenia and thrombocytopenia occurred in $23 \%$ and $26 \%$ of patients, respectively [97].

\section{Alemtuzumab}

Alemtuzumab is a humanized IgG1 kappa monoclonal antibody that binds to CD52, a protein present on the surface of mature lymphocytes, but not on the stem cells from which they are derived.

Alemtuzumab was first tested in a phase II trial in a series of 15 patients with T-PLL who had failed to achieve a CR with various previous chemotherapies, consisting mostly of pentostatin. Major responses occurred in 11 patients $(73 \%)$ with nine $(60 \%)$ CRs. Median survival from the time of treatment with alemtuzumab was eight months [98].

These preliminary results were confirmed in a study of 39 patients by Dearden et al. The patients received 30 mg Alemtuzumab IV, three times per week, until maximal response was achieved. All but two patients had received prior therapy, including 30 with pentostatin and none had achieved a CR. The ORR was $76 \%$ with $60 \%$ CR and $16 \%$ PR. Patients with serous effusions and hepatic or CNS involvement, or very bulky lymph node masses, responded poorly to therapy. The median DFS was seven months. The median OS for the entire group was 10 months. Survival was significantly longer in patients achieving CR (median, 16 months) relative to those with a PR (median, nine months) and non-responders (median, four months) [87].

The safety and efficacy of alemtuzumab (Campath$1 \mathrm{H})$ was evaluated in a compassionate-use program in 76 previously treated (T-PLL) patients (including four chemotherapy-naive patients). Patients received 3, 10, and $30 \mathrm{mg}$ alemtuzumab IV over the first three days, followed 
by $30 \mathrm{mg}$ IV three times per week, for 4 to 12 weeks. The overall response rate was $51 \%$ with a $39.5 \%$ complete response rate (CRR). The median time to progression was 4.5 months, and median duration of CR 8.7 months. The median OS was 7.5 months. Ten patients experienced 15 infectious episodes during treatment (13\%), leading to treatment discontinuation for three, and two treatmentrelated deaths [99].

In a pilot study (UKCLL05), nine previously untreated patients with T-PLL received $30 \mathrm{mg}$ alemtuzumab subcutaneously, three times per week, until maximal response, for a maximum of 18 weeks. Three patients responded to treatment, all with a CR, for a CRR of $33 \%$. Two patients $(22 \%)$ died while on treatment. The outcome of these patients was compared with those of 32 treatment-naive patients with T-PLL who received alemtuzumab IV. These cases were managed similarly to those of the UKCLL05 patients. The ORR was 91\%, with $81 \%$ CR. One half of the patients underwent stem cell transplantation after alemtuzumab therapy. The progression-free survival (PFS) at 12 months was 67\% for both theIV and subcutaneously treated groups, with OS at 48 months of $37 \%$ and $33 \%$, respectively. This finding demonstrated significantly lower response rates for subcutaneous administration of alemtuzumab relative to that administered IV as front-line therapy and the study was halted [100].

\section{Alemtuzumab + chemotherapy}

A prospective multicenter phase II trial of the German CLL Study Group (GCLLSG) analyzed a combination chemotherapy of fludarabine , Mitoxantrone, and cyclophosphamide (FCM) followed by alemtuzumab consolidation in previously treated $(n=9)$ and treatmentnaive $(n=16)$ patients with T-PLL. Patients received FMC, for up to four cycles, followed by alemtuzumab (A) consolidation, for up to 12 weeks. Of the 25 patients treated with FMC, 21 subsequently received alemtuzumab. The ORR to FMC was $68 \%$, comprising six CR and 11 PR. Alemtuzumab consolidation increased the intent-totreat ORR to $92 \%$ (12 CR; 11 PR). Median OS and PFS were 17.1 and 11.9 months, respectively. PFS tended to be shorter for patients with high-level TCL-1 expression. The most frequent grade 3/4 side effects under FMC-A were hematological toxicities. Among the 21 alemtuzumabconsolidated patients, 13 developed cytomegalovirus reactivations, of whom nine presented a clinically relevant infection [92].

Alemtuzumab was evaluated in a phase II trial in combination with pentostatin in 24 patients with a variety of T-cell leukemias and lymphomas. Thirteen patients had T-PLL, of whom eight had prior treatment with a median of two regimens. Patients received $30 \mathrm{mg}$ alemtuzumab IV, three times weekly, for up to three months, and pentostatin at a dose of $4 \mathrm{mg} / \mathrm{m}^{2} \mathrm{IV}$ weekly for four weeks, followed by alternate weekly administration for up to six months. Nine patients responded to treatment (eight CRs [CRR: $62 \%$ ] and one PR), for an ORR of $69 \%$. The median OS and PFS for patients with T-PLL were 10.2 and 7.8 months, respectively. The median event-free survival time for the responding patients with T-PLL was 20 months. Opportunistic infections, including cytomegalovirus reactivation, were common and there were five treatmentrelated deaths [101].

\section{Bendamustine}

Bendamustine is a nitrogen mustard used in the treatment of chronic lymphocytic leukemia and indolent lymphomas. It displays a unique pattern of cytotoxicity, relative to conventional alkylating agents, and shows only partial cross-resistance with other DNA-binding anticancer agents and no cross-resistance with other alkylating agents.

Fifteen patients with T-PLL received bendamustine IV at a dose of $70-120 \mathrm{mg} / \mathrm{m}^{2} / \mathrm{d}$ over $30-60 \mathrm{~min}$, on days 1 and 2, every three weeks for an intended total of six cycles, with T-PLL. Seven patients received bendamustine after frontline alemtuzumab failure, two were treated after multiple therapies, and six were treated in the front line setting. Three patients $(20 \%)$ achieved CR and five (33.3\%) PR, for an ORR of 53.3\%. The median PFS and OS were five and 8.7 months, respectively. PFS and OS did not correlate with alemtuzumab exposure or the line of treatment. Grade 3-4 neutropenia and thrombocytopenia were documented in three $(20 \%)$ and two patients $(13 \%)$, respectively [102].

\section{Stem-cell transplantation}

Several case reports suggested a possible benefit from an immune graft-versus-leukemia (GVL) effect in T-PLL [103-108], leading several groups to investigate SCT in T-PLL. Several studies have suggested that allogeneic SCT may consolidate the response to initial chemotherapy and improve leukemic control and longterm survival in patients with T-PLL following induction treatment; however, it is associated with a significant rate of toxicity [93, 109-111].

SCT following alemtuzumab treatment was investigated in a multicentric series of 28 patients. Fifteen patients were consolidated with an autologous-SCT (median age: 58 years) and thirteen with an allogenic-SCT (median age: 51 years). Eleven patients were in their first $\mathrm{CR}$, two in a second CR, and two in PR at the time of autologous-SCT. All 15 patients achieved CR following the autograft. Transplant-related mortality (TRM) was $7 \%$. Nine patients $(60 \%)$ relapsed at a median of 15 months. The median survival of the autograft patients was 52 months from the start of alemtuzumab treatment. At the time of allogenic-SCT, nine patients $(69 \%)$ were in their 
first CR and four (31\%) in PR. Twelve patients achieved a CR (92\%). There were two cases of early and two of delayed TRM (31\%), all for patients who received fullintensity conditioning. Four patients relapsed and died of progressive disease $(31 \%)$, of whom all had sibling allografts. The median survival of the allograft patients was 33 months. All survivors had a matched unrelated donor. The median survival of all SCT patients was 48 months [57]. A retrospective control group of 23 nontransplanted patients (median age: 64 years) was selected based on achieved CR and survival $>6$ months following alemtuzumab (in $39 \%$ of cases as first line). The median OS of the control group was only 20 months. Their fiveyear OS rate was $0 \%$, whereas that of all transplanted patients was $34 \%$ [93].

The EBMT and Royal Marsden Consortium registry analyzed 41 T-PLL patients (median age: 51 years) that were allotransplanted in a salvage-like setting. The median time from diagnosis to treatment was 12 months. Eleven patients (27\%) were in CR, twelve in PR (29\%), thirteen had stable or progressive disease $(32 \%)$, and the status of five was unknown (12\%). Their lower pretransplant CR rate was probably due, in part, to the small proportion of patients who received alemtuzumab (24\%) prior to allogenic SCT. A total of 13 patients (31\%) received reduced-intensity conditioning (RIC), and 65\% of all myeloablative conditioning consisted of Total body irradiation (TBI). The three-year relapse-free survival (RFS) and OS were $19 \%$ and $21 \%$, respectively, based on a median follow-up of surviving patients of 36 months. Multivariate analysis showed TBI and a $<12$-month interval between diagnosis and HSCT to be associated with a favorable RFS. Three-year non-relapse-related mortality and relapse were each $41 \%$, with most relapses occurring within the first year [109].

A multicenter CIBMTR registry (1995-2006) on 21 T-PLL (among $47 \mathrm{~B}$ - and T-PLL) patients after allogenic-SCT reported median PFS of 5.1 months at a short 13-month follow-up. The one-year OS for the entire cohort was $48 \%$ with median OS of 11.2 months. There were no significant differences in the one-year OS between patients treated with non-myeloablative or myeloablative transplant. There were also no significant differences based on sibling versus matched unrelated donor transplant, age, or whether the patient was in first CR or not [110].

The French society for stem cell transplantation (SFGM-TC) reported the outcome of 27 T-PLL cases. Prior to allogenic-SCT, 14 patients (52\%) were in CR, 10 $(37 \%)$ in PR, and three were refractory or had progressive disease $(11 \%)$. The median time from diagnosis to HSCT was 8.5 months. Among the patients, $48 \%$ and $33 \%$ had received only one or two lines of pre-SCT treatments, respectively. Alemtuzumab constituted the most frequent pre-SCT therapy, $(n=14$; all in first line setting). Following SCT, 21 patients (78\%) achieved CR. Ten
(37\%) were still alive in CR based on a median followup for surviving patients of 33 months. The three-year PFS and OS were $26 \%$ and $36 \%$, respectively. After SCT, $47 \%$ of patients relapsed at a median of 11.7 months. The overall cumulative incidence of TRM was $31 \%$ after three years [111].

Allogenic SCT may improve OS in patients with T-PLL after induction by alemtuzumab, especially for those in first CR and allotransplanted in the first year after diagnosis. A reduced conditioning regimen can help reduce TRM, currently from $30-40 \%$. The relapse rate is still significant at $30-40 \%$ and improvement of the response to induction therapy is an important option. The best treatment for relapse remains to be found, but may include donor lymphocyte infusions in allotransplanted patients aided by monitoring of minimal residual disease by flow cytometry or PCR or NGS [112].

However, the diverse situations and outcomes and ongoing search for more effective regimens, as recently reported by Herling, highlight the need for extensive optimization of the allo-SCT procedures and the resolution of several issues. These include reducing TRM, pausing the administration of pre-SCT alemtuzumab for sustained engraftment, and identifying predictors that involve the success of conditioning [113].

Otherwise, only $30-50 \%$ of patients with T-PLL can benefit from allogenic SCT. Autologous SCT may be another option for patients who are in generally good condition and aged 65 years or less.

\section{New approaches}

T-PLL is an aggressive disease with a poor outcome that needs new therapeutic approaches. After alemtuzumab treatment, most patients rapidly relapse. Allotransplanted patients have a longer median survival, but allogenic-SCT is only suitable for a minority of patients.

Cytogenetic and molecular analysis shows that T-PLL exhibits substantial mutational activation of the TCL-1-AKT and MTCP1 proto-oncogenes, the IL2RG-JAK1-JAK3STAT5B axis, or somatic mutations in genes involved in DNA binding and chromatin remodeling, or epigenetic regulation, that could be candidates for targeted therapies.

\section{AKT inhibitors}

The primary event in T-PLL is the inv(14)/t $(14 ; 14)$ or $\mathrm{t}(\mathrm{X} ; 14)$, leading to activation of TCL1A or MTCP1, respectively. Both proteins interact with the AKT kinase and activate the AKT pathway. Thus, novel agents that target this pathway could be a treatment option in T-PLL.

The preclinical efficacy of the AKT inhibitor, MK2206, was explored on leukemic T-cells isolated from T-PLL patients. The AKT inhibitor, MK-2206 was able to induce dose-dependent apoptosis of isolated PBMCs (containing $>90 \%$ leukemic T-cells) of T-PLL patients $(n=4)(\mathrm{IC} 50: 5 \mu \mathrm{M})$ [15].

Recently, the AKT inhibitor MK-2206 was evaluated in a phase II trial in 59 patients with relapsed or 
refractory lymphoma. It was administered orally at $200 \mathrm{mg}$ once weekly in 28-day cycles, for up to 12 cycles, in the absence of progression or significant toxicity. The dose was adjusted, based on tolerance, and finally, 33 patients received $300 \mathrm{mg}$, two $250 \mathrm{mg}, 16200 \mathrm{mg}$, and eight 135 mg. Eight patients experienced an objective response (two CR and six PR, overall response rate $14 \%$ ), with a median duration of response of 5.8 months. The median duration of EFS in all patients was 2.8 months. The most common toxicity observed in this study was rash (any Grade 53\%, Grade 3 15\%). These promising results show that MK2206 could be a potential therapeutic agent for T-PLL patients [114].

\section{Epigenetic therapy}

$\mathrm{EZH} 2$ is the catalytic subunit of the polycomb repressive complex 2 (PRC2) and is responsible for tri-methylation of histone 3 lysine 27 (H3K27), a mark of transcriptional repression. Recurrent gain-offunction mutations and overexpression of EZH2 drive and promote malignant transformation, such as B-cell lymphomagenesis [115-117]. EZH2 also plays a role in T-cell differentiation and mutations of EZHZ have been found in various T-cell malignancies. Several epigenetic mutations were reported in T-PLL, including a frameshift mutation in the SET domain of EZH2, providing a rationale for inhibiting EZH2 as a potential anti T-PLL strategy [4].

\section{Anti EZH2 inhibitor-GSK2816126}

GSK2816126 is a highly selective and potent inhibitor of both wild type and mutant EZH2, decreases H3K27 tri-methylation, releases transcriptional repression of PRC2 target genes, and induces anti-proliferative activity in several wild type and mutant EZH2 cancer cell lines. GSK2816126 was investigated in a combined phase I accelerated plus classic $3+3$ study, with adaptive Bayesian design dose escalation, in 30 patients with relapsed/refractory lymphomas, solid tumors, and multiple myeloma. Patients received two IV doses weekly for 21 days (3 weeks-on/1 week-off) in a 28-day cycle. GSK2816126 was well tolerated with no DLTs observed. Dose expansion is ongoing at 3,000 $\mathrm{mg}$ given IV twice weekly ( 21 days/28 days). The most frequent drug-related adverse events reported were fatigue (53\%), nausea (30\%), anemia (20\%), and vomiting (20\%). Of 22 evaluable patients, one, an advanced GCB + DLBCL patient, had a confirmed durable PR. Seven patients had stable disease, including an advanced FL patient with $45 \%$ tumor regression and a cholangiocarcinoma patient with stable disease lasting $>6$ cycles [118].

\section{JAK inhibitors}

Mutations in the JAK-STAT pathway occur frequently, especially JAK3 mutations, which have been reported in 21$42 \%$ of T-PLL, suggesting that T-PLL patients could benefit from JAK inhibitors, mostly JAK3 inhibitors.
Several early studies reported reduced cell growth, increased apoptosis, and reduced survival following treatment with JAK3 inhibitors in different experimental systems expressing the above-mentioned activating JAK3 mutations [119-122]. These results provided proof-ofprinciple evidence that JAK3 inhibitors could provide a therapeutic benefit to patients with hematological malignancies carrying activating JAK3 mutations.

However, several issues remain to be resolved, because some patients have more than one JAK mutation and the coexistence of JAK1 and JAK3 [40], which would lead to treatment resistance with either JAK1 or JAK3 kinase inhibitors. Indeed, JAK inhibitors are confronted with eventual treatment resistance, as are other tyrosine kinase inhibitors that target one specific part of the enzyme, typically the ATP-binding pocket; the mutation of a single amino acid can result in resistance of the oncogenic kinase. Furthermore, a new mechanism of acquisition of resistance to JAK inhibitors was recently reported. Cells transformed by a JAK3 mutation became resistant to a JAK3-selective inhibitor by acquiring another activating mutation in JAK1, whereas cells that originally had a JAK1-activating mutation became resistant to inhibitors by acquiring another activating mutation in JAK3, highlighting the cooperation between JAK1 and JAK3 mutants in T-cell transformation [123]. The therapeutic combination of JAK3- and JAK1-selective inhibitors could be an option, as they have been shown to act synergistically on the growth of JAK 3 mutant cells in a T-ALL mouse model [124]. Finally, JAK inhibitors could be used in combination with current therapies.

\section{Tofacinib}

Tofacitinib (CP-690,550) is an oral, small-molecule JAK inhibitor, FDA-USA-approved in 2012 for the treatment of rheumatoid arthritis, that demonstrated high selectivity for JAK3 inhibition with an enzyme inhibitory potency of $1 \mathrm{nmol} / \mathrm{L}$ and showed 20- to 100-fold less selectivity for JAK2 and JAK1, respectively [125].

CP-690,550 was tested in a human NKCL xenograft mouse model, and deactivate the dissemination of MEC04 NKCL cells to the bone marrow, blood, and spleen. CP690,550 could be hindered cell proliferation, viability, metastatic dissemination, and survival of malignant cells in NKCL [122].

\section{Ruxolitinib}

Ruxolitinib is a USA-FDA approved selective JAK $1 / 2$ inhibitor for the treatment of myeloproliferative neoplasms, including intermediate or high risk myelofibrosis and polycythemia vera in patients who did not respond well to, or did not tolerate, hydroxyurea.

Recent evidence suggests that mutations in the JAK/STAT pathway may play an essential role in the pathogenesis of cutaneous T-cell lymphoma (CTCL). Perez et al. detected somatic mutations in either JAK1 or JAK3 genes in up to 7 patients and 1 cell line among 
a total of forty-six patients and two cell lines, most located in the pseudokinase domain. They then analyzed the biological effects of the specific inhibition of JAK/ STAT signaling in human CTCL cell lines, including HuT-78 cells carrying mutated JAK1 and JAK3 genes, by incubating them with increasing doses of ruxolitinib (INCB018424). The cells exhibited activated basal STAT phosphorylation in the absence of serum, possibly due to multiple activating mechanisms including, but not restricted to, JAK mutations. They showed dose-dependent inhibition of cell proliferation and rapid inhibition of STAT activation, including in the HuT-78 cell line. In contrast, they reported the induction of only moderate cytotoxicity by JAK inhibition, suggesting that inhibition of the JAK/STAT pathway does not simply have a direct cytotoxic effect, but efficiently prevents malignant cell growth in CTCL through other mechanisms as well. [126]. Ruxolitinib is being studied in relapsed B-cell NHL and PTCL (NCT01431209).

Several other agents are currently being evaluated for various indications and could be tested in T-PLL: decernotinib (VX-509), a selective oral JAK3 inhibitor, which showed 25-120-fold selectivity for JAK3 over other JAKs (JAK1, JAK2, and TYK2) based on similar cellbased assays [127], peficitinib (ASP015K), an oral JAK1/ JAK3 inhibitor, which also inhibited IL-2-dependent $T$ cell proliferation in vitro and STAT5 phosphorylation in vitro and ex vivo [128], and filgotinib (GLPG0634), a selective oral JAK1 inhibitor [129].

The challenge for these second-generation inhibitors will be to show better specific selectivity within the JAK family with a more manageable safety profile and a better prognosis during long-term/chronic usage.

\section{STAT5 inhibitors}

The selective STAT5 inhibitor, pimozide, which is active in myeloid leukemia, induces a specific and profound reduction in cell proliferation, viability, and pSTAT5 levels of STAT5-activated cells (HUT78 cells), as well as primary T-PLL cells [4], and could also be another targeted treatment.

\section{PARP inhibitors}

The concept of synthetic lethality consists of the simultaneous inactivation of two genes to causes cell death, whereas cells remain viable following inactivation of either of the two genes alone. Poly (ADP-ribose) polymerase (PARP) inhibition requires DNA double strand break repair and should selectively sensitize ATM-dysfunctional cells to die, by inducing conversion of one form of DNA damage into another. The sensitivity to the poly (ADP-ribose) polymerase inhibitor olaparib (AZD2281) was investigated in vitro in ATM mutant lymphoid tumors. Pharmacologic inhibition of tumor cell growth was ATM-dependent and was mediated through mitotic catastrophe, independently of apoptosis. Olaparib treatment also sensitized ATM-null tumor cells to DNA-damaging agents [130].

\section{Immunotherapy combined with epigenetic therapy}

A recent study consisted of adding 2CDA-cladribine and anti-HDAC inhibitors to the monoclonal antibodyanti CD52-alemtuzumab. The rationale of the study was based on the ability of 2CDA-cadribine, a purine analogue with known hypomethylating activity to synergistically increase the expression of silenced tumor suppressors, when combined with anti-HDAC inhibitors, promoting cell death. Nine patients with T-PLL were treated with alemtuzumab and cladribine, with or without an HDAC inhibitor (vorinostat or valproic acid or romidepsine), under various conditions (refractory or relapse, or initial presentation). Eight patients achieved $\mathrm{CR}$ and one PR. One patient received an allogeneic transplant and remains in complete remission. The others all relapsed. Retreatment of the patients after relapse was effective, and the administration of epigenetic agents overcame initial alemtuzumab resistance. The authors hypothesized that epigenetic drugs induce increases in antibody-dependent cell mediated cytotoxicity (ADCC) [131].

The same group showed the induction of CD30 after epigenetic therapy in T-PLL cells by proteomic and transcriptomic analysis, but the mechanism by which epigenetic agents induce the expression of CD30 is not completely understood. In this context, a patient in the fifth line setting presenting with refractory skin lesions, was treated with the antibody drug conjugate, brentuximab vedotin. A biopsy showed lymphocytes testing weakly positive for CD30 surface expression infiltrating the dermis. The patient achieved CR but relapsed five months later with systemic disease [132].

\section{CONCLUSIONS}

T-PLL is a rare disease with a poor prognosis. Flow cytometry has led to better characterization of the cells involved in this disease and cytogenetics and molecular biology have revealed much about its pathophysiology. The genetic causes and oncogenic signaling events responsible for the malignant transformation of T-PLL are yet to be discovered.

T-PLL has a particular genomic and transcriptomic profile with a complex karyotype and recurrent chromosomal abnormalities of several genes involved in cell cycle regulation, apoptosis, DNA repair, and epigenetic modulation [3, 17-19, 22-28, 30, 31]

Conventional treatment has provided disappointing results. Treatment with alemtuzumab significantly improves survival relative to other agents used to treat T-PLL. IV administration should be the preferred route. Alemtuzumab in combination with pentostatin or another purine analogue should be considered for patients not responding to alemtuzumab, mostly those with very aggressive tumor forms or extramedullary localization. Nevertheless, the response to alemtuzumab is often transient and consolidation by SCT should be discussed 
with all patients who achieve complete remission and who are otherwise eligible. However, this procedure is reserved only for the minority of patients in good general condition.

Prospective trials to define the most effective therapeutic strategy and improve clinical responses to frontline therapy are necessary. New approaches using well-tolerated targeting therapies involving growth and survival signals are needed for the majority of patients unable to receive intensive chemotherapy.

\section{Author contributions}

$\mathrm{KL}$ and ABM wrote the manuscript. ABM submitted the manuscript. PL and JS performed the immunohistochemical studies. All authors read and approved the final manuscript.

\section{CONFLICTS OF INTEREST}

There are no conflicts of interest to report for K.L., P.L., J.S., and A.B.M.

\section{REFERENCES}

1. Matutes E, Brito-Babapulle V, Swansbury J, Ellis J, Morilla R, Dearden C, Sempere A, Catovsky D. Clinical and laboratory features of 78 cases of T-prolymphocytic leukemia. Blood. 1991; 78:3269-3274.

2. Chen $X$, Cherian S. Immunophenotypic characterization of T-cell prolymphocytic leukemia. Am J Clin Pathol. 2013; 140:727-735.

3. Pekarsky Y, Hallas C, Croce CM. Molecular basis of mature T-cell leukemia. JAMA. 2001; 286: 2308-2314.

4. Kiel MJ, Velusamy T, Rolland D, Sahasrabuddhe AA, Chung F, Bailey NG, Schrader A, Li B, Li JZ, Ozel AB, Betz BL, Miranda RN, Medeiros LJ, et al. Integrated genomic sequencing reveals mutational landscape of T-cell prolymphocytic leukemia. Blood. 2014; 124:1460-1472.

5. Matutes E, Garcia Talavera J, O'Brien M, Catovsky D. The morphological spectrum of T-prolymphocytic leukaemia. $\mathrm{Br}$ J Haematol. 1986; 64:111-124.

6. Jayakar V, Cheung K, Yebra-Fernandez E, Bain BJ. The distinctive cytological features of T-cell prolymphocytic leukemia. Am J Hematol. 2017; 92:830-832.

7. Dearden CE. How I treat prolymphocytic leukemia. Blood. 2012; $120: 538-551$.

8. Foroni L, Foldi J, Matutes E, Catovsky D, O’Connor NJ, Baer R, Forster A, Rabbitts TH, Luzzatto L. Alpha, beta and gamma T-cell receptor genes: rearrangements correlate with haematological phenotype in T cell leukaemias. Br J Haematol. 1987; 67:307-318.

9. Garand R, Goasguen J, Brizard A, Buisine J, Charpentier A, Claisse JF, Duchayne E, Lagrange M, Segonds C, Troussard X, Flandrin G. Indolent course as a relatively frequent presentation in T-prolymphocytic leukaemia. $\mathrm{Br}$ J Haematol. 1998; 103:488-494.

10. Sugimoto T, Imoto S, Matsuo Y, Kojima K, Yasukawa M, Murayama T, Kohfuku J, Mizuno I, Yakushijin K, Sada A, Nishimura R, Koizumi T. T-cell receptor gamma delta T-cell leukemia with the morphology of T-cell prolymphocytic leukemia and a post thymic immunophenotype. Ann Hematol. 2001; 80:749-751.

11. Gilleece MH, Dexter TM. Effect of Campath-1H antibody on human hematopoietic progenitors in vitro. Blood. 1993; 82:807-812.

12. Matutes E, Coelho E, Aguado MJ, Morilla R, Crawford A, Owusu-Ankomah K, Catovsky D. Expression of TIA-1 and TIA-2 in T cell malignancies and T cell lymphocytosis. J Clin Pathol. 1996; 49:154-158.

13. Hoehn D, Medeiros LJ, Chen SS, Tian T, Jorgensen JL, Ahmed Y, Lin P. CD117 expression is a sensitive but nonspecific predictor of FLT3 mutation in T acute lymphoblastic leukemia and T/myeloid acute leukemia. Am J Clin Pathol. 2012; 137:213-219.

14. Bellone M, Svensson AM, Zaslav AL, Spitzer S, Golightly M, Celiker M, Hu Y, Ma Y, Ahmed T. Pediatric T-cell prolymphocytic leukemia with an isolated 12(p13) deletion and aberrant CD117 expression. Exp Hematol Oncol. 2012; 1:7.

15. Zhang H, Braggio E, Davila J, Feldman AL, Call TG, Witzig TE, Lin Y, Secreto C, Patnaik MM, Cerhan JR, Parikh SA, Baheti S, Ding W. Novel phenotypic and genetic analysis of T-cell prolymphocytic leukemia (T-PLL). Blood. 2014; 124:1682.

16. Tse E, So CC, Cheung WW, Kwong YL. T-cell prolymphocytic leukaemia: spontaneous immunophenotypical switch from CD4 to CD8 expression. Ann Hematol. 2011; 90:479-481.

17. Schlegelberger B, Himmler A, Bartles H, Kuse R, Sterry $\mathrm{W}$, Grote W. Recurrent chromosome abnormalities in peripheral T-cell lymphoma. Cancer Genet Cytogenet. 1994; 78:15-22.

18. Pekarsky Y, Hallas C, Croce CM. The role of TCL1 in human T-cell leukemia. Oncogene. 2001; 20:5638-5643.

19. Maljaei SH, Brito-Babapulle V, Hiorns LR, Catovsky D. Abnormalities of chromosomes 8, 11, 14, and $\mathrm{X}$ in T-prolymphocytic leukemia studied by fluorescence in situ hybridization. Cancer Genet Cytogenet. 1998; 103:110-116.

20. Herling M, Patel KA, Teitell MA, Konopleva M, Ravandi F, Kobayashi R, Jones D. High TCL1 expression and intact $\mathrm{T}$-cell receptor signaling define a hyperproliferative subset of T-cell prolymphocytic leukemia. Blood. 2008; 111:328-337.

21. Stern MH, Soulier J, Rosenzwajg M, Nakahara K, CankiKlain N, Aurias A, Sigaux F, Kirsch IR. MTCP-1: a novel gene on the human chromosome Xq28 translocated on the $\mathrm{T}$ cell receptor alpha/delta locus in mature $\mathrm{T}$ cell proliferations. Oncogene. 1993; 8:2475-2483. 
22. Heinonen K, Mahlamaki E, Hamalainen E, Nousiainen T, Mononen I. Multiple karyotypic abnormalities in three cases of small cell variant of T-cell prolymphocytic leukemia. Cancer Genet Cytogenet. 1994; 78:28-35.

23. Brito-Babapulle V, Catovksy D. Inversions and tandem translocations involving chromosome $14 \mathrm{q} 11$ and $14 \mathrm{q} 32$ in T-prolymphocytic leukemia and T-cell leukemias in patients with ataxia telangiectasia. Cancer Genet Cytogenet. 1991; 55:1-9.

24. Soulier J, Pierron G, Vecchione D, Garand R, Brizard F, Sigaux F, Stern MH, Aurias A. A complex pattern of recurrent chromosomal losses and gains in T-cell prolymphocytic leukemia. Genes Chromosomes Cancer. 2001; 31:248-254.

25. Narducci MG, Stoppacciaro A, Imada K, Uchiyama T, Virgilio L, Lazzeri C, Croce CM, Russo G. TCL1 is overexpressed in patients affected by adult T-cell Leukemias. Cancer Res. 1997; 57:5452-5456.

26. Pekarsky Y, Koval A, Hallas C, Bichi R, Tresini M, Malstrom S, Russo G, Tsichlis P, Croce CM. Tcl1 enhances Akt kinase activity and mediates its nuclear translocation. Proc Natl Acad Sci USA. 2000; 97:3028-3033.

27. Saitou M, Sugimoto J, Hatakeyama T, Russo G, Isobe M. Identification of the TCL6 genes within the breakpoint cluster region on chromosome 14q32 in T-cell leukemia. Oncogene. 2000; 19:2796-2802.

28. Durig J, Bug S, Klein-Hitpass L, Boes T, Jöns T, MartinSubero JI, Harder L, Baudis M, Dührsen U, Siebert R. Combined single nucleotide polymorphism-based genomic mapping and global gene expression profiling identifies novel chromosomal imbalances, mechanisms and candidate genes important in the pathogenesis of T-cell prolymphocytic leukemia with inv(14)(q11q32). Leukemia. 2007; 21:2153-2163.

29. Brito-Babapulle V, Pomfret M, Matutes E, Catovsky D. Cytogenetic studies on prolymphocytic leukemia. II. T cell prolymphocytic leukemia. Blood. 1987; 70:926-931.

30. Mocoska AJ, Trybus TM, Benson PD, Sakr WA, Grignon DJ, Wojno KD, Pietruk T, Powell IJ. Evidence for three tumor suppressor gene loci on chromosome $8 \mathrm{p}$ in human prostate cancer. Cancer Res. 1995; 55:5390-5395.

31. Chang M, Tsuchiya K, Batchelor RH, Rabinovitch P. S., Kulander B. G., Haggitt R. C., Burmer G. C. Deletion mapping of chromosome $8 \mathrm{p}$ in colorectal carcinoma, and dysplasia arising in ulcerative colitis, prostate carcinoma, and malignant fibrous histiocytomas. Am J Pathol. 1994; 144:1-6.

32. Kerangueven F, Essioux L, Dib A, Noguchi T, Allione F, Geneix J, Longy M, Lidereau R, Eisinger F, Pébusque MJ. Loss of heterozygosity and linkage analysis in breast carcinoma: indication for a putative third susceptibility gene on the short arm of chromosome 8. Oncogene. 1995; 10:1023-1026.

33. Taylor AM, Byrd PJ. Molecular pathology of ataxia telangiectasia. J Clin Pathol. 2005; 58:1009-1015.
34. Nowak D, Toriellec EL, Stern MH, Kawamata N, Akagi T, Dyer MJ, Hofmann WK, Ogawa S, Koeffler HP. Molecular allelokaryotyping of T-cell prolymphocytic leukemia cells with high density single nucleotide polymorphism arrays identifies novel common genomic lesions and acquired uniparental disomy. Haematologica. 2009; 94:518-527.

35. Salomon-Nguyen F, Brizard F, Le Coniat M, Radford I, Berger R, Brizard A. Abnormalities of the short arm of chromosome 12 in $\mathrm{T}$ cell prolymphocytic leukaemia. Leukemia. 1998; 12:972-975.

36. de Oliveira FM, Tone LG, Simões BP, Rego EM, Marinato AF, Jácomo RH, Falcão RP. Translocations $t(X ; 14)$ (q28;q11) and $\mathrm{t}(\mathrm{Y} ; 14)(\mathrm{q} 12 ; \mathrm{q11})$ in T-cell prolymphocytic leukemia. Int J Lab Hematol. 2009; 31:453-456.

37. Chiang YC, Teng SC, Su YN, Hsieh FJ, Wu KJ. c-Myc directly regulates the transcription of the NBS1 gene involved in DNA double-strand break repair. J Biol Chem. 2003; 278:19286-19291.

38. Chen YC, Su YN, Chou PC, Chiang WC, Chang MC, Wang LS, Teng SC, Wu KJ. Overexpression of NBS1 contributes to transformation through the activation of phosphatidylinositol 3-kinase/Akt. J Biol Chem. 2005; 280:32505-32511.

39. Kisseleva T, Bhattacharya S, Braunstein J, Schindler CW. Signaling through the JAK/STAT pathway, recent advances and future challenges.Gene. 2002; 285:1-24.

40. Bellanger D, Jacquemin V, Chopin $\mathrm{M}$, Pierron $\mathrm{G}$, Bernard OA, Ghysdael J, Stern MH. Recurrent JAK1 and JAK3 somatic mutations in T-cell prolymphocytic. Leukemia. 2014; 28:417-419.

41. Bergmann AK, Schneppenheim S, Seifert M, Betts MJ, Haake A, Lopez C, Maria Murga Penas E, Vater I, Jayne S, Dyer MJ, Schrappe M, Dührsen U, Ammerpohl O, et al. Recurrent mutation of JAK3 in T-cell prolymphocytic leukemia. Genes Chromosomes Cancer. 2014; 53:309-16.

42. Stengel A, Kern W, Zenger M, Perglerová K, Schnittger S, Haferlach T, Haferlach C. Genetic characterization of T-PLL reveals two major biologic subgroups and JAK3 mutations as prognostic marker. Genes Chromosomes Cancer. 2016; 55:82-94.

43. Sherr CJ, Roberts JM. Living with or without cyclins and cyclin-dependent kinases. Genes Dev. 2004; 18:2699-2711.

44. Le Toriellec E, Despouy G, Pierron G, Gaye N, Joiner M, Bellanger D, Vincent-Salomon A, Stern MH. Haploinsufficiency of CDKN1B contributes to leukemogenesis in T-cell prolymphocytic leukemia. Blood. 2008; 111:2321-2328.

45. López C, Bergmann AK, Paul U, Murga Penas EM, Nagel I, Betts MJ, Johansson P, Ritgen M, Baumann T, Aymerich M, Jayne S, Russell RB, Campo E, et al. Genes encoding members of the JAK-STAT pathway or epigenetic regulators are recurrently mutated in T-cell prolymphocytic leukaemia. Br J Haematol. 2016; 173:265-273.

46. Zhang H, Tian S, Braggio E, Feldman AL, Ketterling RP, He R, Call TG, Witzig TE, Parikh SA, Lin Y, Secreto 
$\mathrm{CR}$, Andersson EI, Mustjoki S, et al. Novel Mutations in NOTCH and Altered Wnt/ $\beta$-Catenin Pathway Indicate a Role of Embryonic Signals in the Pathogenesis of T-Cell Prolymphocytic Leukemia. Blood. 2016; 128:Abstract 4103.

47. Swerdlow SH, Campo E, Harris NL, Jaffe ES, Pileri SA, Stein H, Thiele J, Vardiman JW. WHO Classification of Tumours of Haematopoietic and Lymphoid Tissue. 4th ed. Lyon, France: IARC; 2008.

48. Ravandi F, O'Brien S, Jones D, Lerner S, Faderl S, Ferrajoli A, Wierda W, Garcia-Manero G, Thomas D, Koller C, Verstovsek S, Giles F, Cortes J, et al. T-cell prolymphocytic leukemia: a single-institution experience. Clin Lymphoma Myeloma. 2005; 6:234-239.

49. Khullar G, Singh S, Agrawal S, Sachdeva MU, Saikia UN. Linear nonpalpable purpura in a young male: a unique presentation of leukemia cutis in T-cell prolymphocytic leukemia. Int J Dermatol. 2017; 56:e65-e67.

50. Krassas N, de la Mata Perez G, Jones N. Intraocular T-cell Prolymphocytic Leukemia Masquerading as Necrotizing Herpetic Retinitis. Ocul Immunol Inflamm. 2016; 1-3.

51. Swerdlow SH. International Agency for Research on Cancer, World Health Organization. WHO classification of tumours of haematopoietic and lymphoid tissues. 4th ed. Lyon: International Agency for Research on Cancer; 2008.

52. Lamy T, Moignet A, Loughran TP Jr. LGL leukemia: from pathogenesis to treatment. Blood. 2017; 129:1082-1094. Review.

53. Bareau B, Rey J, Hamidou M, Donadieu J, Morcet J, Reman O, Schleinitz N, Tournilhac O, Roussel M, Fest T, Lamy T. Analysis of a French cohort of patients with large granular lymphocyte leukemia: a report on 229 cases. Haematologica. 2010; 95:1534-41.

54. Gentile TC, Uner AH, Hutchison RE, Wright J, Ben-Ezra J, Russell EC, Loughran TP Jr. CD3+, CD56+ aggressive variant of large granular lymphocyte leukemia. Blood. 1994; 84:2315-2321

55. Matutes E, Wotherspoon AC, Parker NE, Osuji N, Isaacson PG, Catovsky D. Transformation of T-cell large granular lymphocyte leukaemia into a high-grade large T-cell lymphoma. Br J Haematol. 2001; 115:801-6

56. Alekshun TJ, Tao J, Sokol L. Aggressive T-cell large granular lymphocyte leukemia: a case report and review of the literature. Am J Hematol. 2007; 82:481-5.

57. Zhang L, Ramchandren R, Papenhausen P, Loughran TP, Sokol L. Transformed aggressive $\gamma \delta$-variant T-cell large granular lymphocytic leukemia with acquired copy neutral loss of heterozygosity at $17 \mathrm{q} 11.2 \mathrm{q} 25.3$ and additional aberrations. Eur J Haematol. 2014; 93:260-4.

58. Garrido P, Ruiz-Cabello F, Bárcena P, Sandberg Y, Cantón J, Lima M, Balanzategui A, González M, López-Nevot MA, Langerak AW, García-Montero AC, Almeida J, Orfao A. Monoclonal TCR-Vbeta13.1+/CD4+/NKa+/ CD8-/+dim T-LGL lymphocytosis: evidence for an antigen-driven chronic T-cell stimulation origin. Blood. 2007; 109:4890-4898.
59. Lima M, Almeida J, Dos Anjos Teixeira M, Alguero Md Mdel C, Santos AH, Balanzategui A, Queirós ML, Bárcena P, Izarra A, Fonseca S, Bueno C, Justiça B, Gonzalez M, et al. TCR alpha beta+/CD4+ large granular lymphocytosis: a new clonal T-cell lymphoproliferative disorder. Am J Pathol. 2003; 163:763-771.

60. Man C, Au WY, Pang A, Kwong YL. Deletion 6q as a recurrent chromosomal aberration in T-cell large granular lymphocyte leukemia. Cancer Genet Cytogenet. 2002; 139:71-4.

61. Taswell HF, Winkelmann RK. Sezary syndrome a malignant reticulemic erythroderma. JAMA 1961;177:465-472.

62. Willemze R, Jaffe ES, Burg G, Cerroni L, Berti E, Swerdlow SH, Ralfkiaer E, Chimenti S, Diaz-Perez JL, Duncan LM, Grange F, Harris NL, Kempf W, et al. WHOEORTC classification for cutaneous lymphomas. Blood. 2005; 105:3768-3785.

63. Hwang ST, Janik JE, Jaffe ES, Wilson WH. Mycosis fungoides and Sézary syndrome. Lancet. 2008; 371:945-957.

64. Novelli M, Fava P, Sarda C, Ponti R, Osella-Abate S, Savoia P, Bergallo M, Lisa F, Fierro MT, Quaglino P. Blood flow cytometry in Sézary syndrome: new insights on prognostic relevance and immunophenotypic changes during followup. Am J Clin Pathol. 2015; 143:57

65. Lima M, Almeida J, dos Anjos Teixeira M, Queiros ML, Santos AH, Fonseca S, Balanzategui A, Justica B, Orfao A. Utility of flow cytometry immunophenotyping and DNA ploidy studies for diagnosis and characterization of blood involvement in CD4+ Sézary's syndrome. Haematologica. 2003; 88:874-87.

66. Introcaso CE, Hess SD, Kamoun M, Ubriani R, Gelfand $\mathrm{JM}$, Rook AH. Association of change in clinical status and change in the percentage of the CD4+CD26- lymphocyte population in patients with Sézary syndrome. J Am Acad Dermatol. 2005; 53:428-34.

67. Feng B, Jorgensen JL, Jones D, Chen SS, Hu Y, Medeiros LJ, Wang SA. Flow cytometric detection of peripheral blood involvement by mycosis fungoides and Sézary syndrome using T-cell receptor Vbeta chain antibodies and its application in blood staging. Mod Pathol. 2010; 23:284-95.

68. Ralfkiaer E, Wollf-Sneedorff A, Thomsen K, Vejlsgaard GL. Immunophenotypic studies in cutaneous T-cell lymphoma: clinical implications. Br. J. Dermatol. 1993; 129:655-659.

69. Wu R, Zippin JH, Magro C. Double-positive CD4(+) CD8(+) Sézary syndrome: an unusual phenotype with an aggressive clinical course. Cutis. 2014 Feb;93:E18-25.

70. Barba G, Matteucci C, Girolomoni G, Brandimarte L, Varasano E, Martelli MF, Mecucci C. Comparative genomic hybridization identifies 17q11.2 approximately q12 duplication as an early event in cutaneous T-cell lymphomas. Cancer Genet Cytogenet. 2008; 184:48-51.

71. Caprini E, Cristofoletti C, Arcelli D, Fadda P, Citterich MH, Sampogna F, Magrelli A, Censi F, Torreri P, Frontani M, Scala E, Picchio MC, Temperani P, et al. Identification of key regions and genes important in the pathogenesis of 
sezary syndrome by combining genomic and expression microarrays. Cancer Res. 2009; 69:8438-46.

72. Vermeer MH, van Doorn R, Dijkman R, Mao X, Whittaker S, van Voorst Vader PC, Gerritsen MJ, Geerts ML, Gellrich S, Söderberg O, Leuchowius KJ, Landegren U, Out-Luiting JJ, et al. Novel and highly recurrent chromosomal alterations in Sézary syndrome. Cancer Res. 2008; 68:2689-98.

73. Salgado R, Gallardo F, Servitje O, Estrach T, GarcíaMuret MP, Romagosa V, Florensa L, Serrano S, Salido M, Solé F, Pujol RM, Espinet B. Absence of TCR loci chromosomal translocations in cutaneous T-cell lymphomas. Cancer Genet. 2011; 204:405-9.

74. Mao X, Orchard G, Lillington DM, Child FJ, Vonderheid EC, Nowell PC, Bagot M, Bensussan A, Russell-Jones R, Young BD, Whittaker SJ. BCL2 and JUNB abnormalities in primary cutaneous lymphomas. Br J Dermatol. 2004; 151:546-56.

75. Matutes E. Adult T-cell leukaemia/lymphoma. J Clin Pathol. 2007;60: 1373-1377.

76. Tsukasaki K, Hermine O, Bazarbachi A, Ratner L, Ramos JC, Harrington W Jr, O’Mahony D, Janik JE, Bittencourt AL, Taylor GP, Yamaguchi K, Utsunomiya A, Tobinai K, et al. Definition, prognostic factors, treatment, and response criteria of adult T-cell leukemia-lymphoma: a proposal from an international consensus meeting. J Clin Oncol. 2009;27:453-459.

77. Bittencourt AL, Barbosa HS, Vieira MD, Farré L. Adult T-cell leukemia/ lymphoma (ATL) presenting in the skin: clinical, histological and immunohistochemical features of 52 cases. Acta Oncol. 2009; 48:598-604.

78. Raza S, Naik S, Kancharla VP, Tafera F, Kalavar MR. Dual-positive (CD4+/CD8+) acute adult T-cell leukemia/ lymphoma associated with complex karyotype and refractory hypercalcemia: case report and literature review. Case Rep Oncol. 2010; 3:489-494.

79. Bittencourt AL, de Oliveira Mde F. Cutaneous manifestations associated with HTLV-1 infection. Int J Dermatol. 2010; 49:1099-1110.

80. Tsukasaki K, Krebs J, Nagai K, Tomonaga M, Koeffler HP, Bartram CR, Jauch A. Comparative genomic hybridization analysis in adult T-cell leukemia/lymphoma: Correlation with clinical course. Blood. 2001; 97:3875-3881.

81. Itoyama T, Chaganti RS, Yamada Y, Tsukasaki K, Atogami S, Nakamura H, Tomonaga M, Ohshima K, Kikuchi M, Sadamori N. Cytogenetic analysis and clinical significance in adult T-cell leukemia/lymphoma: A study of 50 cases from the human T-cell leukemia virus type-1 endemic area, Nagasaki. Blood. 2001; 97:3612-3620.

82. Oshiro A, Tagawa H, Ohshima K, Karube K, Uike N, Tashiro Y, Utsunomiya A, Masuda M, Takasu N, Nakamura S, Morishima Y, Seto M. Identification of subtype-specific genomic alterations in aggressive adult T-cell leukemia/ lymphoma. Blood. 2006; 107:4500-4507.

83. Pawson R, Matutes E, Brito-Babapulle V, Maljaie H, Hedges M, Mercieca J, Dyer M, Catovsky D. Sezary cell leukaemia: a distinct $\mathrm{T}$ cell disorder or a variant form of $\mathrm{T}$ prolymphocytic leukaemia? Leukemia. 1997; 11:1009-1013.

84. Brito-Babapulle V, Maljaie SH, Matutes E, Hedges M, Yuille M, Catovsky D. Relationship of T leukaemias with cerebriform nuclei to T-prolymphocytic leukaemia: a cytogenetic analysis with in situ hybridization. Br J Haematol. 1997; 96:724-32.

85. Kussick SJ, Wood BL, Sabath DE. Mature T cell leukemias which cannot be adequately classified under the new WHO classification of lymphoid neoplasms. Leukemia. 2002; 16:2457-8.

86. Herling M, Khoury JD, Washington LT, Duvic M, Keating MJ, Jones D. A systematic approach to diagnosis of mature T-cell leukemias reveals heterogeneity among WHO categories. Blood. 2004; 104:328-35.

87. Dearden CE, Matutes E, Cazin B. Tjønnfjord GE, Parreira A, Nomdedeu B, Leoni P, Clark FJ, Radia D, Rassam SM, Roques T, Ketterer N, Brito-Babapulle V, et al. High remission rate in T-cell prolymphocytic leukemia with CAMPATH-1H. Blood. 2001; 98:1721-1726.

88. Chandran R, Gardiner SK, Fenske TS, Spurgeon ES. Survival trends in T cell prolymphocytic leukemia: A SEER database analysis. Leuk Lymphoma. 2016; 57:942-944.

89. Aoki E, Jain P, Ferrajoli A, Estrov Z, Keating M, O'Brien SM, Wierda WG, Jain N, Thompson PA, Jabbour E, Pierce S, Hosing C, Kantarjian HM, et al. Characteristics, Outcomes and Treatment of Patients with T-Cell Prolymphocytic Leukemia. Blood. 2016; 128:2997.

90. Mercieca J, Matutes E, Dearden C, MacLennan K, Catovsky D. The role of pentostatin in the treatment of T-cell malignancies: analysis of response rate in 145 patients according to disease subtype. J Clin Oncol. 1994; 12:2588-2593.

91. Ho AD, Suciu S, Stryckmans P, De Cataldo F, Willemze R, Thaler J, Peetermans M, Döhner H, Solbu G, Dardenne M, Zittoun R, Leukemia Cooperative Group. Pentostatin in T-cell malignancies-a phase II trial of the EORTC. Leukemia Cooperative Group. Ann Oncol. 1999; 10:1493-1498.

92. Hopfinger G, Busch R, Pflug N, Weit N, Westermann A, Fink AM, Cramer P, Reinart N, Winkler D, FingerleRowson G, Stilgenbauer S, Döhner H, Kandler G, et al. Sequential chemoimmunotherapy of fludarabine, mitoxantrone, and cyclophosphamide induction followed by alemtuzumab consolidation is effective in T-cell prolymphocytic leukemia. Cancer. 2013; 119:2258-67.

93. Krishnan B, Else M, Tjonnfjord GE, Cazin B, Carney D, Carter J, Ketterer N, Catovsky D, Ethell M, Matutes E, Dearden CE. Stem cell transplantation after alemtuzumab in T-cell prolymphocytic leukaemia results in longer survival than after alemtuzumab alone: a multicentre retrospective study. Br J Haematol. 2010; 149:907-910.

94. Kurtzberg J, Ernst TJ, Keating MJ, Gandhi V, Hodge JP, Kisor DF, Lager JJ, Stephens C, Levin J, Krenitsky T, Elion G, Mitchell BS. Phase I study of $506 \mathrm{U} 78$ administered on a consecutive 5-day schedule in children and adults with 
refractory hematologic malignancies. J Clin Oncol. 2005; 23:3396-3403.

95. Berg SL, Blaney SM, Devidas M, Lampkin TA, Murgo A, Bernstein M, Billett A, Kurtzberg J, Reaman G, Gaynon P, Whitlock J, Krailo M, Harris MB; Children's Oncology Group. Phase II study of nelarabine (compound 506U78) in children and young adults with refractory T-cell malignancies: a report from the Children's Oncology Group. J Clin Oncol. 2005; 23:3376-3382.

96. Cohen MH, Johnson JR, Massie T, Sridhara R, McGuinn WD Jr, Abraham S, Booth BP, Goheer MA, Morse D, Chen XH, Chidambaram N, Kenna L, Gobburu JV, et al. Approval summary: Nelarabine for the treatment of T-cell lymphoblastic leukemia/lymphoma. Clin Cancer Res. 2006; 12:5329-5335.

97. Gandhi V, Tam C, O’Brien S, Jewell RC, Rodriguez CO Jr, Lerner S, Plunkett W, Keating MJ. Phase I trial of nelarabine in indolent leukemias. J Clin Oncol. 2008; 26:1098-1105.

98. Pawson R, Dyer MJ, Barge R, Matutes E, Thornton PD, Emmett E, Kluin-Nelemans JC, Fibbe WE, Willemze R, Catovsky D. Treatment of T-cell prolymphocytic leukemia with human CD52 antibody. J Clin Oncol. 1997; 15:2667-2672.

99. Keating MJ, Cazin B, Coutré S, Birhiray R, Kovacsovics T, Langer W, Leber B, Maughan T, Rai K, Tjønnfjord G, Bekradda M, Itzhaki M, Hérait P. Campath-1H treatment of T-cell prolymphocytic leukemia in patients for whom at least one prior chemotherapy regimen has failed. J Clin Oncol. 2002; 20:205-213.

100. Dearden CE, Khot A, Else M, Hamblin M, Grand E, Roy A, Hewamana S, Matutes E, Catovsky D. Alemtuzumab therapy in T-cell prolymphocytic leukemia: comparing efficacy in a series treated intravenously and a study piloting the subcutaneous route. Blood. 2011; 118:5799-5802.

101. Ravandi F, Aribi A, O’Brien S, Faderl S, Jones D, Ferrajoli A, Huang X, York S, Pierce S, Wierda W, Kontoyiannis D, Verstovsek S, Pro B, et al. Phase II study of alemtuzumab in combination with pentostatin in patients with T-cell neoplasms. J Clin Oncol. 2009; 27:5425-5430.

102. Herbaux C, Genet P, Bouabdallah K, Pignon JM, Debarri H, Guidez S, Betrian S, Leleu X, Facon T, Morschhauser F, Damaj G, Cazin B, Ysebaert L. Bendamustine is effective in T-cell prolymphocytic leukaemia. Br J Haematol. 2015; 168:916-919.

103. Collins RH, Pineiro LA, Agura ED, Fay JW. Treatment of $\mathrm{T}$ prolymphocytic leukemia with allogeneic bone marrow transplantation. Bone Marrow Transplant. 1998; 21: 627-628.

104. Garderet L, Bittencourt H, Kaliski A, Daniel M, Ribaud P, Socié G, Gluckman E. Treatment of T-prolymphocytic leukemia with non myeloablative allogeneic stem cell transplantation. Eur J Haematol. 2001; 66: 137-139.

105. de Lavallade H, Faucher C, Fürst S, El-Cheikh J, Vey N, Coso D, Bouabdallah R, Stoppa AM, Gastaut JA, Blaise D, Mohty M. Allogeneic stem cell transplantation after reduced-intensity conditioning in a patient with T-cell prolymphocytic leukemia: graft-versus tumor effect and long-term remission. Bone Marrow Transplant. 2006; 37:709-710.

106. Kruspe RC, Ashraf KK, Foran JM, Salzman DE, Reddy VV, Vaughan WP. Successful treatment of T-cell prolymphocytic leukemia with full-intensity conditioning followed by matched unrelated donor allogeneic stem cell transplantation. Clin Adv Hematol Oncol. 2007; 5:882-884.

107. Tanimoto TE, Hirano A, Nagafuji K, Yamasaki S, Hashiguchi M, Okamura T, Kamezaki K, Takase K, Numata A, Miyamoto T, Fukuda T, Harada M. Mismatched unrelated cord blood transplantation in a patient with T-cell prolymphocytic leukemia. Leukemia 2005; 19: 679-681.

108. Murase K, Matsunaga T, Sato T, Kuribayashi K, Kogawa K, Kawano Y, Okamoto T, Takayama T, Watanabe H, Niitsu Y, Hirayama Y. Allogeneic bone marrow transplantation in a patient with T-prolymphocytic leukemia with smallintestinal involvement. Int J Clin Oncol. 2003; 8: 391-394.

109.Wiktor-Jedrzejczak W, Dearden C, de Wreede L, van Biezen A, Brinch L, Leblond V, Brune M, Volin L, Kazmi M, Nagler A, Schetelig J, de Witte T, Dreger P; EBMT Chronic Leukemia Working Party. Hematopoietic stem cell transplantation in T-prolymphocytic leukemia: a retrospective study from the European Group for Blood and Marrow Transplantation and the Royal Marsden Consortium. Leukemia. 2012; 26: 972-976.

110. Kalaycio ME, Kukreja M, Woolfrey AE, Szer J, Cortes J, Maziarz RT, Bolwell BJ, Buser A, Copelan E, Gale RP, Gupta V, Maharaj D, Marks DI, et al. Allogeneic hematopoietic cell transplant for prolymphocytic leukemia. Biol Blood Marrow Transplant. 2010; 16:543-547.

111. Guillaume T, Beguin Y, Tabrizi R, Nguyen S, Blaise D, Deconinck E, Redjoul R, Cornillon J, Guillerm G, Contentin N, Sirvent A, Turlure P, Salmon A, et al. Allogeneic hematopoietic stem cell transplantation for T-prolymphocytic leukemia: a report from the French society for stem cell transplantation (SFGM-TC). Eur J Haematol. 2015; 94:265-269.

112. Sellner L, Brüggemann M, Schlitt M, Knecht H, Herrmann D, Reigl T, Krejci A, Bystry V, Darzentas N, Rieger $\mathrm{M}$, Dietrich S, Luft $\mathrm{T}$, Ho AD, et al. GvL effects in T-prolymphocytic leukemia: evidence from MRD kinetics and TCR repertoire analyses. Bone Marrow Transplant. 2017; 52:544-551.

113.Herling M. Are we improving the outcome for patients with T-cell prolymphocytic leukemia by allogeneic stem cell transplantation? Eur J Haematol. 2015 ; 94:191-2.

114. Oki Y, Fanale M, Romaguera J, Fayad L, Fowler N, Copeland A, Samaniego F, Kwak LW, Neelapu S, Wang M, Feng L, Younes A. Phase II study of an AKT inhibitor MK2206 in patients with relapsed or refractory lymphoma. Br J Haematol. 2015 ; 171:463-70.

115. Morin RD, Johnson NA, Severson TM, Mungall AJ, An J, Goya R, Paul JE, Boyle M, Woolcock BW, Kuchenbauer F, 
Yap D, Humphries RK, Griffith OL, et al. Somatic mutations altering EZH2 (Tyr641) in follicular and diffuse large B-cell lymphomas of germinal-center origin. Nat Genet. 2010; 42:181-185.

116. Morin RD, Mendez-Lago M, Mungall AJ, Goya R, Mungall KL, Corbett RD, Johnson NA, Severson TM, Chiu R, Field M, Jackman S, Krzywinski M, Scott DW, et al. Frequent mutation of histone-modifying genes in nonHodgkin lymphoma. Nature. 2011; 476:298-303.

117. Okosun J, Bodör C, Wang J, Araf S, Yang CY, Pan C, Boller S, Cittaro D, Bozek M, Iqbal S, Matthews J, Wrench D, Marzec J, et al. Integrated genomic analysis identifies recurrent mutations and evolution patterns driving the initiation and progression of follicular lymphoma. Nat Genet. 2014; 46:176-181.

118. Yap TA, Winter JN, Leonard JP, Ribrag V, Constantinidou A, Giulino-Roth L, Michot JM, Khan TA, Horner T, Carver J, Dumetrescu TP, He Z, McCabe MT, et al. A Phase I Study of GSK2816126, an Enhancer of Zeste Homolog 2(EZH2) Inhibitor, in Patients (pts) with Relapsed/Refractory Diffuse Large B-Cell Lymphoma (DLBCL), Other Non-Hodgkin Lymphomas (NHL), Transformed Follicular Lymphoma (tFL), Solid Tumors and Multiple Myeloma (MM). Blood. 2016; 128:4203.

119. Sato T, Toki T, Kanezaki R, Xu G, Terui K, Kanegane H, Miura M, Adachi S, Migita M, Morinaga S, Nakano T, Endo M, Kojima S, et al. Functional analysis of JAK3 mutations in transient myeloproliferative disorder and acute megakaryoblastic leukaemia accompanying Down syndrome. Br J Haematol. 2008; 141:681-688.

120. Elliott NE, Cleveland SM, Grann V, Janik J, Waldmann TA, Dave UP. FERM domain mutations induce gain of function in JAK3 in adult T-cell leukemia/lymphoma. Blood. 2011; 118: 3911-3921.

121. Koo GC, Tan SY, Tang T, Poon SL, Allen GE, Tan L, Chong SC, Ong WS, Tay K, Tao M, Quek R, Loong S, Yeoh KW, et al. Janus kinase 3-activating mutations identified in natural killer/T-cell lymphoma. Cancer Discov. 2012; 2:591-597.

122. Bouchekioua A, Scourzic L, de Wever O, Zhang Y, Cervera P, Aline-Fardin A, Mercher T, Gaulard P, Nyga R, Jeziorowska D, Douay L, Vainchenker W, Louache F, et al. JAK3 deregulation by activating mutations confers invasive growth advantage in extranodal nasal-type natural killer cell lymphoma. Leukemia. 2014; 28:338-348.

123. Springuel L, Hornakova T, Losdyck E, Lambert F, Leroy E, Constantinescu SN, Flex E, Tartaglia M, Knoops L, Renauld JC. Cooperating JAK1 and JAK3 mutants increase resistance to JAK inhibitors. Blood. 2014; 124:3924-3931.
124. Degryse S, de Bock CE, Cox L, Demeyer S, Gielen O, Mentens N, Jacobs K, Geerdens E, Gianfelici V, Hulselmans G, Fiers M, Aerts S, Meijerink JP, et al. JAK3 mutants transform hematopoietic cells through JAK1 activation, causing T-cell acute lymphoblastic leukemia in a mouse model. Blood. 2014; 124:3092-3100.

125. Changelian PS, Flanagan ME, Ball DJ, Kent CR, Magnuson KS, Martin WH, Rizzuti BJ, Sawyer PS, Perry BD, Brissette WH, McCurdy SP, Kudlacz EM, Conklyn MJ, et al. Prevention of organ allograft rejection by a specific Janus kinase 3 inhibitor. Science. 2003; 302:875-878.

126. Pérez C, González-Rincón J, Onaindia A, Almaráz C, García-Díaz N, Pisonero H, Curiel-Olmo S, Gómez S, Cereceda L, Madureira R, Hospital M, Suárez-Massa D, Rodriguez-Peralto JL, et al. Mutated JAK kinases and deregulated STAT activity are potential therapeutic targets in cutaneous T-cell lymphoma. Haematologica. 2015 ; 100:e450-453.

127. Mahajan S, Hogan JK, Shlyakhter D, Oh L, Salituro FG, Farmer L, Hoock TC. VX-509 (decernotinib) is a potent and selective janus kinase 3 inhibitor that attenuates inflammation in animal models of autoimmune disease. $\mathrm{J}$ Pharmacol Exp Ther. 2015; 353:405-414.

128. Yamazaki S, Morio H, Inami M, Ito M, Fujii Y, Hanaoka K, Yamagami K, Okuma K, Morita Y, Shirakami S, Inoue T, Miyata S, Higashi Y, et al. ASP015K: A novel JAK inhibitor demonstrated potent efficacy in adjuvant-induced arthritis model in rats. Ann Rheum Dis. 2013; 72:A197.

129. Van Rompaey L, Galien R, van der Aar EM, ClementLacroix P, Nelles L, Smets B, Lepescheux L, Christophe T, Conrath K, Vandeghinste N, Vayssiere B, De Vos S, Fletcher S, et al. Preclinical characterization of GLPG0634, a selective inhibitor of JAK1, for the treatment of inflammatory diseases. J Immunol. 2013 ; 191:3568-3577.

130. Weston VJ, Oldreive CE, Skowronska A, Oscier DG, Pratt G, Dyer MJ, Smith G, Powell JE, Rudzki Z, Kearns P, Moss PA, Taylor AM, Stankovic T. The PARP inhibitor olaparib induces significant killing of ATM-deficient lymphoid tumor cells in vitro and in vivo. Blood. 2010; 116:4578-4587.

131. Hasanali ZS, Saroya BS, Stuart A, Shimko S, Evans J, Vinod Shah M, Sharma K, Leshchenko VV, Parekh S, Loughran TP Jr, Epner EM. Epigenetic therapy overcomes treatment resistance in T cell prolymphocytic leukemia. Sci Transl Med. 2015; 7: 293ra102.

132. Epner EM, Saroya BS, Hasanali ZS, Loughran TP Jr. Combination epigenetic and immunotherapy overcomes resistance to monoclonal antibodies in hematologic malignancies: A new therapeutic approach. Exp Hematol. 2016; 44:157-160. 